\title{
Eifelian (Middle Devonian) to Lower Frasnian (Upper Devonian) conodont biostratigraphy in the Villech section (Spanish Central Pyrenees)
}

\author{
SOFIE GOUWY, JAU-ChYN LIAO \& JOSÉ IGNACIO VALENZUELA-RÍOS
}

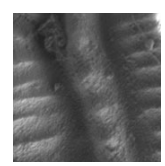

\begin{abstract}
Conodont biostratigraphic research on the Comabella Formation at Villech (Spanish Central Pyrenees), a $54 \mathrm{~m}$ thick pinkish-greyish compact hemipelagic limestone section situated in the Compte "subfacies area", reveals an Eifelian to early Frasnian age for the studied interval. The base of the Formation is of lower Eifelian age (costatus Zone), indicated by the lowest local record of Polygnathus angustipennatus, associated with P. partitus. The kockelianus and eiflius zones are recognized in the lower half of the section. The uppermost Eifelian and lowermost Givetian (ensensis and hemiansatus zones, respectively) have not been found so far but might be located in a covered interval. Other biozones recognized in the section are the timorensis-rhenanus/varcus, ansatus, semialternans, hermanni, disparilis and norrisi zones in the Givetian, all indicated by their respective index species and the MN1 Zone (occurrence of Ad. binodosa and Ad. pristina) in the Frasnian. A black shale and limestone layer in the upper part of the Villech section could represent the local signature of the upper part of the global Taghanic Crisis. - Key words: conodonts, Middle Devonian, biostratigraphy, Spanish Central Pyrenees.
\end{abstract}

Gouwy, S., LiAO, J.-C. \& VAlENZUELA-Ríos, J.I. 2013. Eifelian (Middle Devonian) to Lower Frasnian (Upper Devonian) conodont biostratigraphy in the Villech section (Spanish Central Pyrenees). Bulletin of Geosciences 88(2), 315-338 (7 figures, 4 tables). Czech Geological Survey, Prague. ISSN 1214-1119. Manuscript received February 3, 2012; accepted in revised form June 11, 2012; published online February 4, 2013; issued June 7, 2013.

Sofie Gouwy (corresponding author), Department of Paleontology, Royal Belgian Institute of Natural Sciences, Vautierstraat 29, B-1000 Brussels, Belgium; sofiegouwy@yahoo.com • Jau-Chyn Liao, Departamento de Paleontología, Facultad de Ciencias Geológicas, Universidad Complutense; c/ Antonio Novais, 2 Ciudad Universitaria; E-28040 Madrid, Spain • Jau-Chyn Liao \& José Ignacio Valenzuela-Ríos, Departamento de Geología, Universitat de València, C/ Dr. Moliner 50; E- 46100 Burjassot, Spain

The Pyrenean Paleozoic rocks are part of the southern flank of the European Variscan Chain where south-verging structures prevail, south of the North Pyrenean Fault Zone. Deformation and magmatism of Paleozoic rocks are mainly Variscan in age while Alpine deformation produced the reactivation of older structures and the structural stacking of Variscan units.

During the Devonian, a complex sedimentation took place in the Central and Eastern Pyrenees. In this region, important lateral changes in Devonian lithologies prompted Mey (1967) to arrange them into four major facies areas. In this subdivision, the concept of subfacies was introduced in the "Southern facies area" by Mey (1967). He distinguished the Sierra Negra, the Baliera, the Renanue and the Compte "subfacies areas" based on the grouping of similar Devonian sequences (Fig. 1B). Some subsequent authors like Boersma (1973) and Zwart (1979) regrouped the stratigraphic units but in this work the original subdivision of the "Southern facies" into four "subfacies" of Mey (1967) (Fig. 1B) is used.
Middle Devonian rocks are widespread in the Spanish Central Pyrenees but only in the last 40 years, studies on this topic have been intensified (Hartevelt 1970, Boersma 1973, Sanz-López 1995, Liao et al. 2001, Valenzuela-Ríos \& Liao 2006, Liao et al. 2008, Liao \& Valenzuela-Ríos 2008). One of the most relevant early works for conodont studies was Boersma (1973). He did the initial conodont studies of several important Middle and Upper Devonian sections, among which also the Villech section that is described here in detail. The same section was also sampled by Valenzuela-Ríos in the course of a Geological Survey. He improved the initial dating of Boersma over the entire Villech section (from the Pragian to the Carboniferous) and realized the potential of the section. A significant part of it is studied in this paper.

The Villech section is located in the Compte "subfacies area", part of the larger "Southern facies area" of Mey (1967) located in the Spanish Central Pyrenees (Figs 1A-C, 2). The upper part of the Emsian, the Middle Devonian and the 


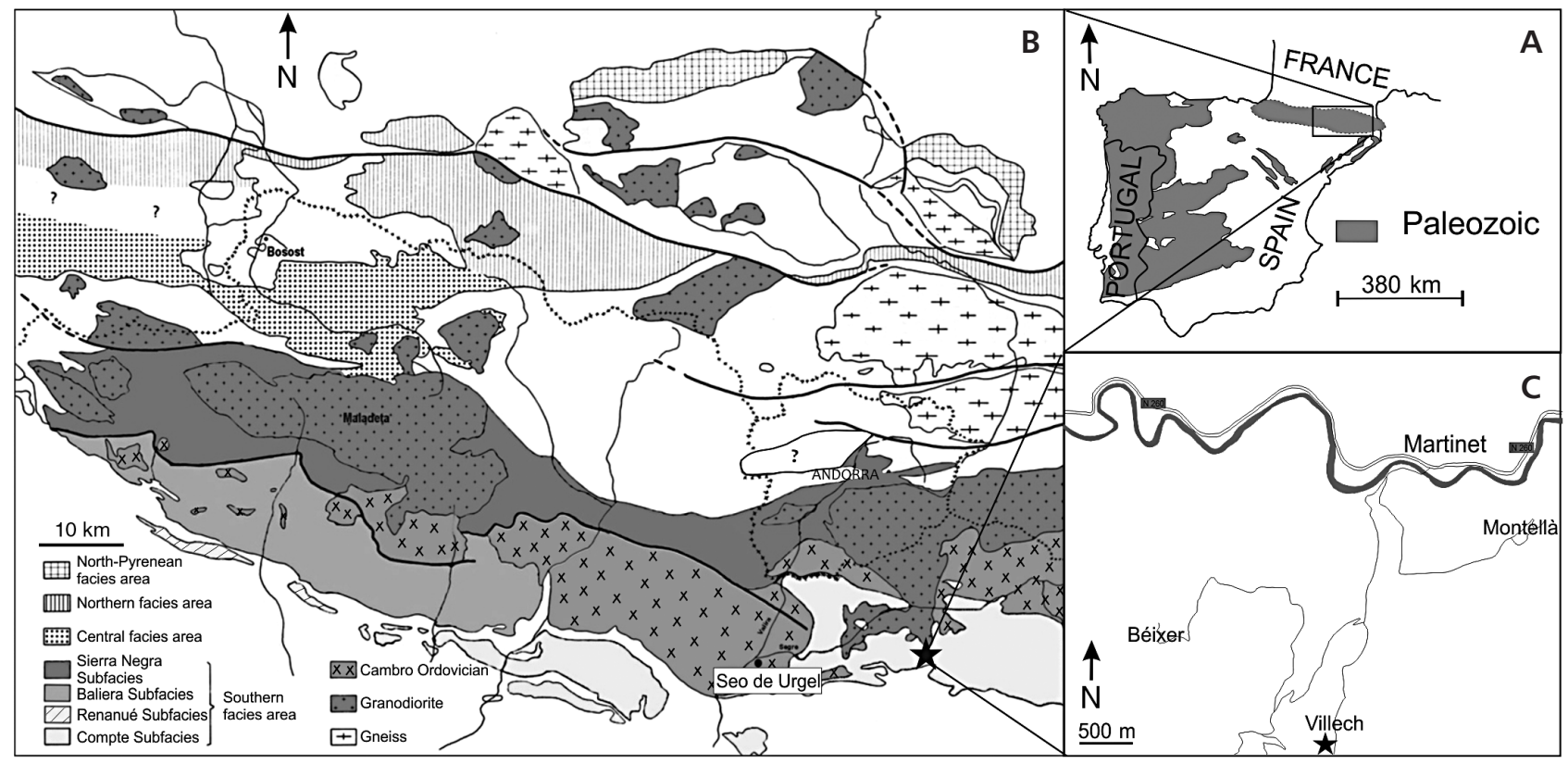

Figure 1. Devonian Facies areas in the Spanish Central Pyrenees (B - after Zwart 1979) and location of the studied section (B, C). Star indicates the position of the section.

Frasnian of the Compte "subfacies area" are represented by the Villech and Comabella Formations. In most sections, the Villech Formation ends within the serotinus Zone (Montesinos \& Sanz-López 1999); in the Serra Comabella section, it can reach the lower part of the patulus Zone, indicating a possible diachronous top of the Formation. The boundary between the Villech and Comabella formations is situated around the boundary between the upper Emsian serotinus and patulus zones (Sanz-López 1995, 2002; Valenzuela-Ríos \& Sanz-López 2002; Valenzuela-Ríos \& Liao 2006).

\section{The Villech section}

The section is partly exposed near the road on the eastern slope of a hill and partly in an abandoned quarry along the road close to the small village of Villech (Fig. 1C). The $54 \mathrm{~m}$ long section is easily accessible with a bit of climbing.

Two lithological formations are exposed in a series of almost continuous outcrops of which only two are studied here (Fig. 2A-H). The Villech Formation is composed of nodular and argillaceous limestones with different amounts of red and green shales. The overlain Comabella
Formation consists of nodular reddish limestones and condensed red beds in the lowermost part of the formation (Fig. 2B, C, E) followed by condensed pinkish-greyish limestones (Fig. 2A, D, H) with hard-ground development (Fig. 2G) and synsedimentary tectonics (Fig. 2H) especially in the uppermost part of the section. The limestone beds are rather poor in number of conodont specimens, although they have a high diversity of conodont taxa.

In this road-cut section, Boersma (1973) recognized the uppermost part of the Basibé Formation, the Villech Formation and what he called the Compte $(\mathrm{A}-\mathrm{C})$ Formation; his Compte A Fm approximately corresponds to the current Comabella Formation. The studied part of the Villech section represents the uppermost Villech Formation and most of the Compte A Member of Boersma (1973). He placed the base of his A Member of the Compte Formation at the base of some thick-bedded grey limestones; about $11 \mathrm{~m}$ above the top of the Villech Formation as conceived in the present study (see Fig. 3). Boersma (1973) situated this level in the kockelianus Zone (1973), corresponding to the present australis-ensensis zones (upper Eifelian) based on the first occurrence of Spathognathodus intermedius. From his uppermost sample of the Compte A Member (sample 435), he mentioned a list of species from which

Figure 2. Images of the Villech section. - A - upper part of the Villech section in the quarry (samples 30-36) scale: the two thick limestone beds in the middle of the picture measure together $3.6 \mathrm{~m}$. $\bullet \mathrm{B}$ - contact between the Villech Formation (right) and Comabella Formation (left). $\bullet \mathrm{C}-$ reddish nodular limestones in the lowermost part of the section (samples 2-5). $\bullet$ D - bedded massive grey limestone in the upper part of the section (here samples $25-26$ ). $\bullet \mathrm{E}$ - fieldwork conditions in the lower part of the section (around sample 23). $\bullet \mathrm{F}$ - thin layer of black shales and limestone (sample 29 ). $\bullet \mathrm{G}-$ hardground with limonite (sample Q-1/1). $\bullet \mathrm{H}$ - synsedimentary tectonics (slumping) around sample 34. 

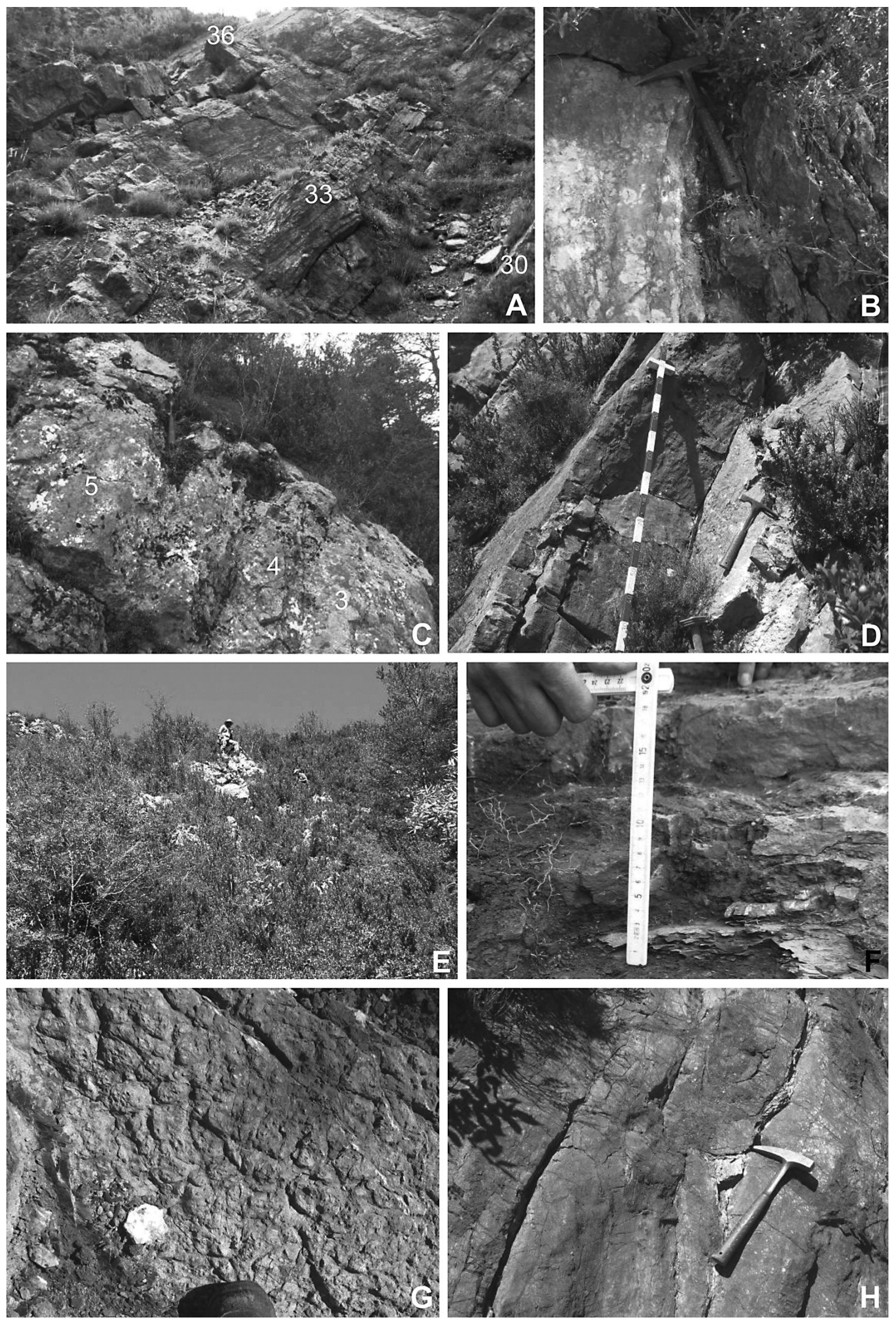
many, according to present conodont biostratigraphy, cannot occur together. The sample either contained pieces from different beds or his identifications are, at least, not all correct. In any case these data should no longer be considered.

Sanz-López (2002) places the nodular lower part of the Comabella Fm. in the costatus Zone; the more condensed red beds are located in the kockelianus Zone and the condensed hemipelagic limestones with hardgrounds in the upper Givetian.

The Villech section (Fig. 3) was sampled during two field campaigns in the summers of 2007 and 2008. During the first field campaign the section was measured in detail and 31 samples were taken for conodont research, during the second campaign 20 extra samples were taken for the refining of the conodont biostratigraphy, based on the preliminary results of the first sampling. Samples from V500 = Vi-I/1 to V620, V1/2, Q-1/1 and Q-1/2 are from the earlier geological survey campaign by Valenzuela-Ríos.

\section{Results}

The conodont elements retrieved from the studied part of the Villech section are moderately preserved (no deformed conodonts, but a lot of broken specimens) and have a colour alteration index of 4-4.5 (dark brown). The diversity of the species in the samples increases with younger age of the samples. The abundance of the conodonts fluctuates though the section although the richest samples are found in the upper part of the section.

Our conodont biostratigraphic study reveals an Eifelian to early Frasnian age for the sampled interval in the Comabella Fm. (Fig. 3, Tables 1-3).

The base of the Comabella Fm. is placed in the lower part of the Eifelian, indicated by the lowest local record of Polygnathus angustipennatus found right above the contact with the underlying Villech Formation (sample Vi-I/1). According to Belka et al. (1997) this species appears in the lowermost part of the costatus Zone.

In sample Vi-I/2, a higher diversity of taxa is found: $P$. partitus, $P$. bultyncki, $P$. robusticostatus and $P$. angustipennatus, an assemblage that places the sample in the lower part of the costatus Zone (Belka et al. 1997, Gouwy $\&$ Bultynck 2002).

The index species of that zone, $P$. costatus first appears in sample $\mathrm{Vi}-\mathrm{I} / 3$, together with $I$. cf. regularicrescens; Polygnathus angusticostatus and P. linguiformis linguiformis make their entry in sample Vi-I/5. These are two species that normally appear within the costatus Zone and both range up into the Givetian.

Tortodus kockelianus australis, the index species for the australis Zone, was not found, so the presence of this zone cannot be stated. T. kockelianus kockelianus appears in sample Vi-I/15, defining the base of the kockelianus Zone and coinciding with the first occurrence of P. pseudofoliatus morphotype $\beta$. Polygnathus eiflius in sample Vi-I/17 marks the base of the eiflius Zone. The finding of $P$. trigonicus in sample $\mathrm{Vi}-\mathrm{I} / 17 \mathrm{t}$ in combination with P. eiflius limits this sample to the eiflius Zone (Belka et al. 1997).

A typical Givetian fauna appears first in sample Vi-I/18A following a covered interval in the section: $P$. ensensis, $P$. hemiansatus and $P$. xylus, a combination that does not occur below the base of the Lower varcus Zone. The covered interval in the section does not allow sampling between $\mathrm{Vi}-\mathrm{I} / 17 \mathrm{t}$ and $18 \mathrm{~A}$, impeding the recovery of data that might indicating the presence of the ensensis and hemiansatus zones.

The ansatus Zone starts almost right above (sample V1/2) with the first occurrence of P. ovatinodosus (Klapper \& Johnson 1980, Gouwy \& Bultynck 2003), followed by the entry of $P$. ansatus (sample V502) and the first occurrence of $P$. linguiformis weddigei (sample Vi-I/19). Halfway this zone, P. timorensis, I. brevis, I. difficilis, $P$. linguiformis mucronatus and $P$. varcus appear for the first time in the section. The level formed by samples Vi-I/23A and V610 seems to mark a higher diversity of species (samples Vi-I/22 and V600 are almost barren). These are all species that normally have their first appearance in the Lower varcus Zone and are making a delayed entry here.

The basis of the semialternans Zone (uppermost part of the Middle varcus Zone) is indicated by the appearance of "O." semialternans in sample Vi-I/26, coinciding with the entry of "O." brevis.

The narrow but distinct layer of black limestone and shales is positioned between samples Q-1\1 and Vi-I/29 within this Zone.

In the upper part of the section, the hermanni, disparilis and norrisi zones are recognized, all indicated by their respective index species. The appearance of Schmidtognathus hermanni pinpoints the base of the hermanni Zone at sample Vi-I/33. Polygnathus aff. cristatus cristatus enters together with $K$. disparilis (sample Q-1\2). Polygnathus dengleri dengleri marks the base of the upper disparilis subzone in sample Vi-I/34. The appearance of Sk. norrisi marks the base of the norrisi Zone, the uppermost conodont zone of the Givetian at sample Vi-I/35. The base of that zone normally coincides with the base of the falsiovalis Zone although Mesotaxis falsiovalis-ovalis only appears here in sample Vi-I/35A, right beneath the appearance of Ancyrodella cf. pristina in sample $\mathrm{Vi}-\mathrm{I} / 36 \mathrm{~A}$.

The Givetian-Frasnian boundary is positioned in the uppermost part of the studied section, between samples $\mathrm{Vi}-\mathrm{I} / 35 \mathrm{~A}$ and $\mathrm{Vi}-\mathrm{I} / 36 \mathrm{~A}$. In the field, a small fault was 


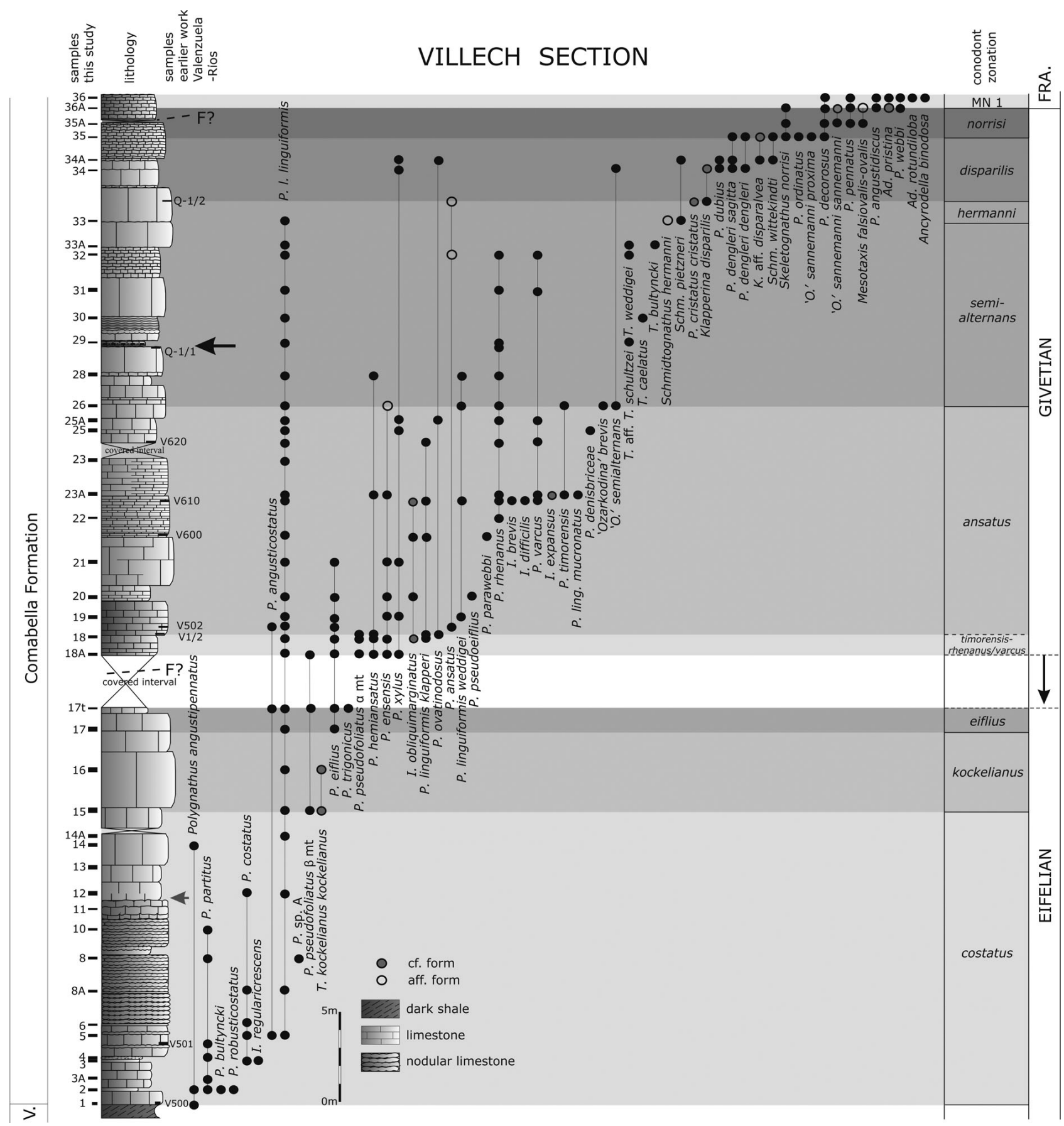

Figure 3. Lithology and conodont distribution of the Villech section. Two possible faults are indicated (F). The Boersma limit between the Villech Formation and the Compte A Member starts at the base of sample Vi-I/12 (grey arrow). The black arrow indicates the position of the black limestone/shale deposit. Samples 1 to 36 are indicated in the text with Vi-I/1 to Vi-I/36. The sample names are shortened in the figure to save space. Samples from an earlier study by Valenzuela-Ríos are indicated on the right side of the lithologic column. The Villech Formation is indicated with the abbreviation V.

inferred between those samples. The occurrence of $A d$. pristina in the latter indicates the base of the Frasnian (within the falsiovalis Zone). Sample 36 shows the joint entry of Ad. rotundiloba s.s. and Ad. binodosa. These first Frasnian beds correspond to the Montagne Noire 1 Zone (MN1, Klapper 1989).

\section{Comparison with another section from the Compte "subfacies area"}

One other section from the Compte "subfacies area" of the Spanish Central Pyrenees was recently studied for its conodont biostratigraphy: the Compte section (Liao \& 
Table 1. Distribution and number of conodonts in the Villech section (part 1).

\begin{tabular}{|c|c|c|c|c|c|c|c|c|c|c|c|c|c|c|c|c|c|c|c|c|c|c|c|c|c|c|c|c|c|c|c|c|c|c|}
\hline & 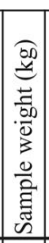 & 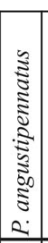 & 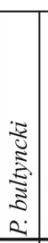 & 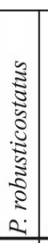 & 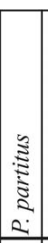 & 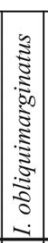 & 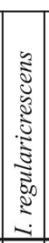 & 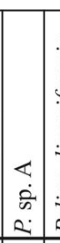 & 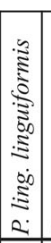 & 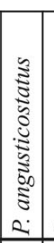 & 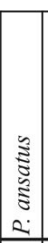 & 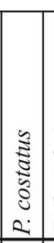 & 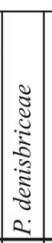 & 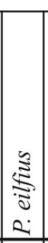 & 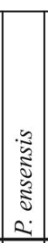 & 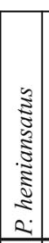 & 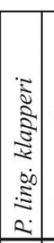 & 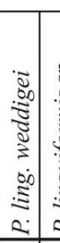 & 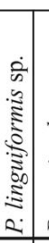 & 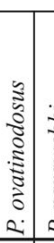 & 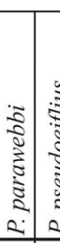 & 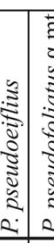 & 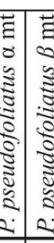 & 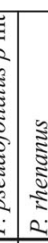 & 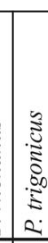 & 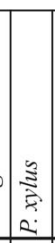 & 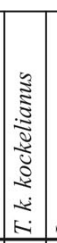 & $\dot{\Delta}$ & $\begin{array}{l}\dot{2} \\
\dot{0} \\
0\end{array}$ & 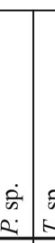 & & 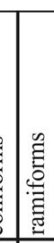 & 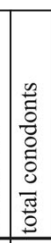 & 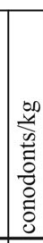 \\
\hline $\begin{array}{l}\text { V500 } \\
\text { Vi-I/1 }\end{array}$ & \begin{tabular}{l|} 
\\
+ \\
\end{tabular} & - & & & & & & & & & & & & & & & & & & & & & & & & & & & & & & & - & $\tilde{O}$ \\
\hline $\mathrm{Vi}-\mathrm{I} / 2$ & 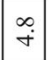 & - & $\sim$ & $\sim$ & - & & & & & & & & & & & & & & & & & & & & & & & $\infty$ & & 우 & & $=$ & $\vec{\sigma}$ & - \\
\hline $\mathrm{Vi}-\mathrm{I} / 3 \mathrm{~A}$ & \begin{tabular}{|l|}
$\infty$ \\
0 \\
6
\end{tabular} & & & & $N$ & & & & & & & & & & & & & & & & & & & & & & & & & $\sim$ & & & $a$ & $\stackrel{n}{=}$ \\
\hline $\mathrm{Vi}-\mathrm{I} / 3$ & $n$ & & & & & & $\stackrel{\breve{\Xi}}{\sim}$ & & & & & $N$ & & & & & & & - & & & & & & & & & 으 & & i & & + & 7 & $\infty$ \\
\hline $\mathrm{Vi}-\mathrm{I} / 4$ & $\stackrel{\sim}{r}$ & & & & - & & & & & & & & & & & & & & & & & & & & & & & - & & $m$ & & & in & $\stackrel{0}{-}$ \\
\hline V501 & $\hat{\mathrm{i}}$ & & & & - & & & & & & & & & & & & & & - & & & & & & & & & $\alpha$ & & & & & t & $\stackrel{+}{\sim}$ \\
\hline $\mathrm{Vi}-\mathrm{I} / 5$ & $\begin{array}{l}\infty \\
\dot{t} \\
\end{array}$ & & & & & & & & $\sim$ & 4 & & $\sigma$ & & & & & & & & & & & & & & & & $\because$ & & $=$ & & N & f & 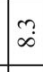 \\
\hline $\mathrm{Vi}-\mathrm{I} / 6$ & $\dot{\nabla}$ & & & & & & & & & & & v & & & & & & & & & & & & & & & & & & r & & N & $=$ & ปี \\
\hline $\mathrm{Vi}-\mathrm{I} / 8 \mathrm{~A}$ & 音 & & & & & & & & $\mathrm{N}$ & & & 4 & & & & & & & & & & & & & & & & & & $r$ & & & $=$ & N \\
\hline $\mathrm{Vi}-\mathrm{I} / 8$ & $\stackrel{n}{m}$ & & & & - & & & $\mathrm{N}$ & & & & & & & & & & & & & & & & & & & & & & in & & $=$ & 2 & in \\
\hline $\mathrm{Vi-I} / 10$ & $\grave{i}$ & & & & - & & & & & & & & & & & & & & & & & & & & & & & & & r & & & $\infty$ & ì \\
\hline $\mathrm{Vi}-\mathrm{I} / 11$ & $\begin{array}{l}\dot{0} \\
\dot{r} \\
\end{array}$ & & & & & & & & & & & & & & & & & & & & & & & & & & & & & $=$ & & & $=$ & $m$ \\
\hline $\mathrm{Vi-I} / 12$ & $\nabla$ & & & & & & & & - & & & - & & & & & & & & & & & & & & & & & & $\infty$ & & N & $\simeq$ & $m$ \\
\hline $\mathrm{Vi}-\mathrm{I} / 13$ & $\stackrel{n}{i}$ & & & & & & & & & & & & & & & & & & & & & & & & & & & & & v & & - & $m$ & $\stackrel{\simeq}{\simeq}$ \\
\hline Vi-I/14 & $\begin{array}{l}\infty \\
\dot{\sim} \\
\end{array}$ & N & & & & & & & & & & & & & & & & & & & & & & & & & & & & - & & $m$ & 0 & 9 \\
\hline $\mathrm{Vi}-\mathrm{I} / 14 \mathrm{~A}$ & $\stackrel{+}{m}$ & & & & & & & & - & & & & & & & & & & & & & & & & & & & & & $m$ & & - & in & $\because$ \\
\hline $\mathrm{Vi-}-\mathrm{I} / 15$ & $\exists \dot{F}$ & & & & & & & & N & & & & & & & & & & & & & & o & $v$ & & & $\ddot{\Xi}$ & & & $\simeq$ & - & $\infty$ & $\stackrel{N}{\circ}$ & 3 \\
\hline $\mathrm{Vi}-\mathrm{I} / 16$ & $\begin{array}{l}0 \\
0 \\
0\end{array}$ & & & & & & & & - & & & & & & & & & & & & & & & & & & 㫕 & & & $\infty$ & v & 4 & \pm & $\bar{i}$ \\
\hline $\mathrm{Vi}-\mathrm{I} / 17$ & $\vec{m}$ & & & & & & & & t & & & & & $m$ & & & & & & & & & & & & & & - & & $\sim-$ & - & - & $\cong$ & $\stackrel{+}{\mathcal{H}}$ \\
\hline $\mathrm{Vi}-\mathrm{I} / 17 \mathrm{t}$ & $\stackrel{n}{\sim}$ & & & & & & & & n & - & & & & - & & & & & & & & & - & - & N & & & $N$ & & $\bar{\sim}$ & & i & in & $\stackrel{m}{=}$ \\
\hline $\mathrm{Vi}-\mathrm{I} / 18 \mathrm{~A}$ & $\vec{i}$ & & & & & & & & 0 & 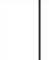 & & & & $m$ & $m$ & t & & & & & & r & $N$ & 0 & & $=$ & & & & $\infty$ & - & m & $\infty$ & 웅 \\
\hline $\mathrm{Vi}-\mathrm{I} / 18$ & $\because$ & & & & & $\stackrel{\breve{\Xi}}{\leftrightarrows}$ & & & 8 & & & & $N$ & - & in & 0 & - & & & & & & - & & & & & & & - & - & $\stackrel{\infty}{\sim}$ & $\Xi$ & $\begin{array}{l}\bar{\infty} \\
\dot{I}\end{array}$ \\
\hline $\mathrm{V} 1 / 2$ & \begin{tabular}{|l|}
$\infty$ \\
in \\
\end{tabular} & & & & & & & & $\stackrel{\infty}{-}$ & & & & & & & $m$ & $\sim$ & & & in & & & $\sim$ & & & & & & & t & & & J & in \\
\hline V502 & $\stackrel{\sim}{\sim}$ & & & & & & & & - & $\sim$ & - & & & $N$ & & & & & & & & & & & & & & & & $m-$ & - & & $\cong$ & $\bar{m}$ \\
\hline $\mathrm{Vi-I} / 19$ & $\vec{m}$ & & & & & & & & q & & & & & - & n & & & $\stackrel{ }{=}$ & & & & & & & & m & & & & n & - & $\stackrel{m}{m}$ & $\hat{n}$ & i \\
\hline $\mathrm{Vi}-\mathrm{I} / 20$ & $\ddot{+}$ & & & & & - & & & in & & & & & \pm & $m$ & & & & & & & - & & & & & & & $\sim$ & - & & $\bar{m}$ & $\infty$ & $\stackrel{\infty}{2}$ \\
\hline $\mathrm{Vi}-\mathrm{I} / 21$ & $\begin{array}{l}\infty \\
\dot{m} \\
\dot{m}\end{array}$ & & & & & & & & N & & & & & - & - & & & & & & & & & & & $n$ & & in & & $m-$ & - & $\cong$ & i & $\stackrel{\infty}{6}$ \\
\hline V600 & $\stackrel{+}{m}$ & & & & & - & & & in & & & & & & & & - & & - & & - & & & & & & & - & & & & & $\subseteq$ & iे \\
\hline $\mathrm{Vi}-\mathrm{I} / 22$ & $\stackrel{m}{+}$ & & & & & & & & & & & & & & & & & & - & & & & & - & & & & t & & & & in & $=$ & $\begin{array}{l}0 \\
i\end{array}$ \\
\hline
\end{tabular}


Table 1. Distribution and number of conodonts in the Villech section (part 2).

\begin{tabular}{|c|c|c|c|c|c|c|c|c|c|c|c|c|c|c|c|c|c|c|c|c|c|c|c|c|c|c|c|c|c|c|c|c|c|c|}
\hline & 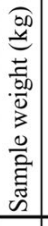 & 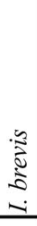 & 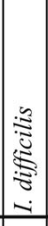 & $\begin{array}{c}3 \\
\vdots \\
\vdots \\
\vdots \\
\vdots \\
\vdots \\
\dot{z} \\
\end{array}$ & 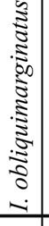 & 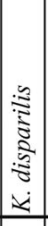 & 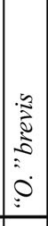 & 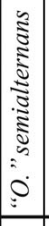 & 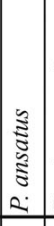 & 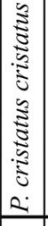 & \begin{tabular}{|c|} 
\\
$\vdots$ \\
$\vdots$ \\
$\vdots$ \\
$\vdots$ \\
2 \\
2 \\
\end{tabular} & 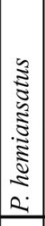 & 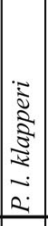 & 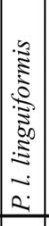 & 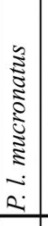 & 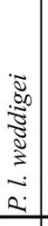 & 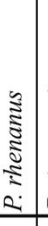 & 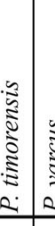 & 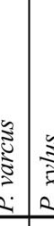 & 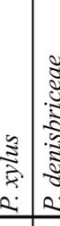 & 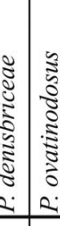 & 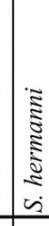 & 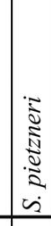 & 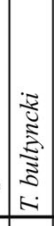 & 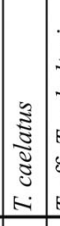 & 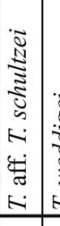 & 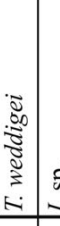 & $\begin{array}{c} \\
\dot{2} \\
\dot{2} \\
\\
\end{array}$ & 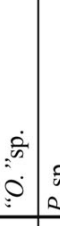 & & 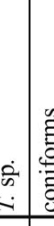 & & 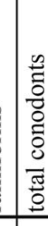 & 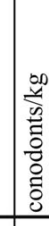 \\
\hline V610 & $\tilde{N}$ & - & 4 & & 岂 & & & & & & & & - & $=$ & & $m$ & N & & $\checkmark$ & & & & & & & & & $\sim$ & - & & & & ते & $\stackrel{7}{2}$ \\
\hline $\mathrm{Vi}-\mathrm{I} / 23 \mathrm{~A}$ & $\stackrel{m}{+}$ & & & 岕 & & & & & & & -1 & - & & 0 & - & & $m$ & -7 & - & & & & & & & & & $\sim$ & & & & n & $\approx$ & $\stackrel{r}{r}$ \\
\hline $\mathrm{Vi}-\mathrm{I} / 23$ & $\stackrel{\sim}{+}$ & & & & & & & & & & & & & N & & & & & & & & & & & & & & & & & & $m$ & in & $=$ \\
\hline V620 & 9 & & & & & & & & & & & & - & $\because$ & & & ते & & $\vec{\sim}$ & & & & & & & & & & $m$ & & $\mathrm{~N}$ & & $\approx$ & ঙั \\
\hline $\mathrm{Vi-} / / 25$ & $\hat{m}$ & & & & & & & & & & & & & in & & & & & & 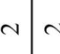 & N & & & & & & & & & & & co & $\approx$ & 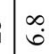 \\
\hline $\mathrm{Vi}-\mathrm{I} / 25 \mathrm{~A}$ & F & & & & & & & & & & & & & 2 & & & $\nabla$ & & $m$ & - & - & & & & & & & & & $a$ & & 그 & $E$ & $\stackrel{n}{=}$ \\
\hline $\mathrm{Vi-I} / 26$ & $\stackrel{r}{q}$ & & & & & & $\sim$ & - & & & $\stackrel{ \pm}{\Xi}$ & & & $n$ & & $\sim$ & $\sim$ & $N$ & - & & & & & & & & & & & o & $\vec{\sigma}$ & $\stackrel{2}{\tau}$ & 2 & $\approx$ \\
\hline $\mathrm{Vi}-\mathrm{I} / 28$ & $F$ & & & & & & & & & & & - & & $\mathrm{N}$ & & - & - & & & & & & & & & & & & & & & c & $\bar{N}$ & $\vec{n}$ \\
\hline $\mathrm{Q}-1 / 1$ & $\stackrel{0}{0}$ & & & & & & & & & & & & & & & & - & & & & & & & & & & & & & & - & & $\sim$ & 3 \\
\hline $\mathrm{Vi}-\mathrm{I} / 29$ & $\stackrel{2}{\therefore}$ & & & & & & & & & & & & & $\bar{\gamma}$ & & t & & & & & & & & & & - & & & & \pm & & & $\approx$ & 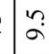 \\
\hline $\mathrm{Vi}-\mathrm{I} / 30$ & $\stackrel{\circ}{+}$ & & & & & & & & & & & & & t & & & & & & & & & & & - & & & & - & & & - in & $\simeq$ & $m$ \\
\hline $\mathrm{Vi}-\mathrm{I} / 31$ & $\hat{n}$ & & & & & & & & & & & & & 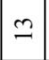 & & & - & & $\nabla$ & & & & & & & & & & & & & 20 & 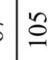 & $\stackrel{+}{\infty}$ \\
\hline $\mathrm{Vi}-\mathrm{I} / 32$ & $\ddot{m}$ & & & & & & & & $\underset{\Xi}{\mathscr{J}}$ & & & & & 6 & & & - & & - & & & & & & & & - & & & & & r & $=$ & n? \\
\hline $\mathrm{Vi}-\mathrm{I} / 33 \mathrm{~A}$ & $\hat{m}$ & & & & & & & & & & & & & \pm & & & & & & & & & & - & & & $N$ & & & 0 & & r & $\stackrel{\infty}{\sim}$ & $\stackrel{\circ}{r}$ \\
\hline Vi-I/33 & $\ddot{m}$ & & & & & & & & & & & & & - & & & & & & & & $\underset{\Xi}{\mathbb{E}}$ & - & & & & & & & & & $\gamma$ & tr & 9 \\
\hline $\mathrm{Q}-1 / 2$ & 0 & & & & & 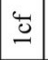 & & & 壹 & 岕 & & & & & & & & & & & & & & & & & & & & & & & $m$ & $?$ \\
\hline
\end{tabular}

Table 1. Distribution and number of conodonts in the Villech section (part 3).

\begin{tabular}{|c|c|c|c|c|c|c|c|c|c|c|c|c|c|c|c|c|c|c|c|c|c|c|c|c|c|c|c|c|c|c|c|c|c|}
\hline & 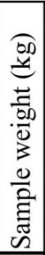 & 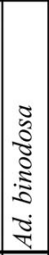 & 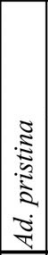 & 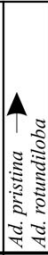 & 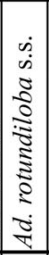 & 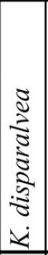 & 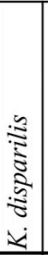 & 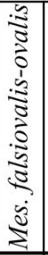 & 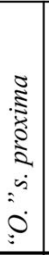 & 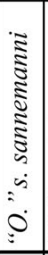 & 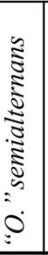 & 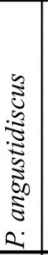 & 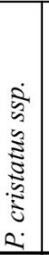 & 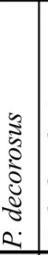 & 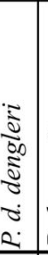 & 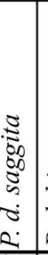 & 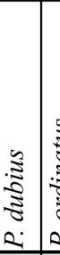 & 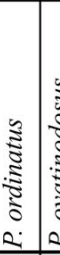 & 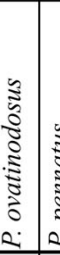 & 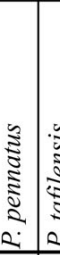 & 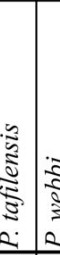 & 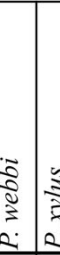 & 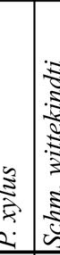 & 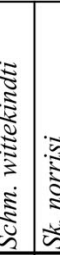 & 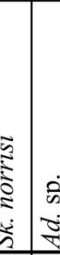 & 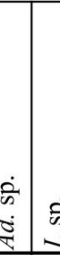 & & $\begin{array}{l}\dot{2} \\
\dot{2} \\
\dot{2}\end{array}$ & $\begin{array}{l}\dot{2} \\
\dot{2} \\
R^{2}\end{array}$ & 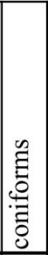 & . & 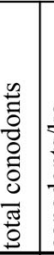 & 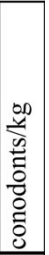 \\
\hline $\mathrm{Vi}-\mathrm{I} / 34$ & $\vec{m}$ & & & & & & $\stackrel{4}{\underline{U}}$ & & & & - & & & & $m$ & 离 & $r$ & & & & & & $\bumpeq$ & & & $\curvearrowright$ & & & N & & શે & ชి & in \\
\hline $\mathrm{Vi}-\mathrm{I} / 34 \mathrm{~A}$ & m? & & & & & $\stackrel{\mathscr{\Xi}}{\Xi}$ & & & & & & & - & & & $r$ & $m$ & & - & & & & - & - & & & $n$ & - & t & & $=$ & 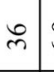 & gे \\
\hline $\mathrm{Vi}-\mathrm{I} / 35$ & $\stackrel{m}{m}$ & & & & & 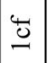 & & & - & & & & N & 으 & - & $N$ & & - & & & & & & - & $m$ & & & & - & & 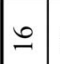 & m. & $\stackrel{\infty}{=}$ \\
\hline $\mathrm{Vi}-\mathrm{I} / 35 \mathrm{~A}$ & ?n? & & & & & & & - & & + & & & $m$ & - & & & & & & - & & & & & - & & & & ナ & & n & त) & $\stackrel{\infty}{m}$ \\
\hline $\mathrm{Vi}-\mathrm{I} / 36 \mathrm{~A}$ & $\stackrel{\triangleright}{\leftarrow}$ & & $\stackrel{\Psi}{\underline{\Xi}}$ & & & & & 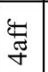 & & 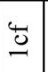 & & - & & 9 & & & & & & $\underline{0}$ & & - & & & N & & & & & & $\hat{\sim}$ & $\begin{array}{c}4 \\
4\end{array}$ & $\stackrel{t}{\bullet}$ \\
\hline $\mathrm{Vi}-\mathrm{I} / 36$ & 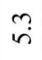 & $\theta$ & $\stackrel{0}{\circ}$ & - & 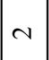 & & & & & & & $m$ & & గ & & & & & & $\begin{array}{l}\infty \\
\infty \\
\infty\end{array}$ & - & $\infty$ & & & & N & & & 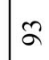 & & + & $\underset{m}{\stackrel{2}{n}}$ & : \\
\hline
\end{tabular}


Valenzuela-Ríos 2008) located in the Compte "subfacies area" (about $50 \mathrm{~km}$ west of the Villech section). The detailed conodont biostratigraphic zonation scheme of this section allows a comparison with the biostratigraphic results of Villech section. The Compte section comprises the Givetian and the lowermost part of the Frasnian. The section shows a higher diversity in conodont taxa compared to the Villech section and comprises several stratigraphically important taxa absent in Villech (I. lindensis, P. latifossatus, $P$. cristatus ectypus, Schm. peracutus, K. ovalis, K. unilabius a.o.). It is considered the reference section for the Givetian of the Spanish Central Pyrenees.

In the Compte section the conodont fauna retrieved from the lowermost part of the section does not allow a distinction between the hemiansatus and timorensis zones; in the Villech section the lowermost sample containing a Givetian fauna (sample right above a covered interval) is assigned to the timorensis- rhenanus/varcus zones. The sample below the covered interval is placed in the eiflius Zone, indicating that the ensensis and hemiansatus zones are covered or maybe missing. So far, in the Compte "subfacies area", no deposits can be with centainty assigned to the ensensis and hemiansatus zones. The timorensis-rhenanus/varcus zones interval and the ansatus Zone have been identified in both sections and demonstrate a considerable variation in thickness of the deposits assigned to those zones. The difference in thickness is also observed in the latifossatus-semialternans Zone in the sections. While reaching only one half meter in the Compte section, the deposits of the semialternans Zone are $10 \mathrm{~m}$ thick in the Villech section. The thickness varies less in the hermanni, disparilis and norrisi zones. In both sections, the base of the Frasnian is marked by the appearance of the first early ancyrodellids.

The inconsistent thickness variation of the deposits in the two sections and/or the possible absence of certain conodont zones suggest synsedimentary tectonic activity in the area in the Middle Devonian (also indicated by the presence of slumps in the Villech section, Fig. $2 \mathrm{H}$ ).

\section{Systematic palaeontology}

The conodont species discussed and illustrated here are the biostratigraphically most relevant ones or conodont specimens with a more problematic identification due to the bad preservation. The specimens of the Villech section are deposited in the conodont collection at the University of Valencia (Spain) and indicated by the according Museum collection numbers (MGUV).

Ozarkodina species in this paper are mentioned as "Ozarkodina" following the reviewed diagnosis of the genus by Murphy et al. (2004). In this reviewed diagnosis the genus name Ozarkodina is restricted to apparatus with $\mathrm{Pa}$ element characterised by (Murphy et al. 2004) a high sail-like or fan-like set of denticles of the anteriormost part of the blade that are separated from the rest of the denticle row by a slight offset, a space or a distinct change in denticulation style. The Pa element has small basal platform lobes and a small basal cavity of which the anterior margin is situated in the anterior half of the blade. A stepped lower profile of the element is common. Species that were formerly classified under this genus but that do not show all these characteristics are here indicated by "Ozarkodina".

\section{Genus Ancyrodella Ulrich \& Bassler, 1926}

Type species. - Ancyrodella nodosa Ulrich \& Bassler, 1926.

\section{Ancyrodella binodosa Uyeno, 1967}

Figure 6F, G

1967 Ancyrodella rotundiloba binodosa n. subsp.; Uyeno, pp. 4, 5, pl. 1, figs 2, 4, 5 .

1980 Ancyrodella binodosa Uyeno. - Bultynck \& Hollard, p. 28, pl. 10, fig. 4.

1981 Ancyrodella binodosa $\delta$ morphotype. - Bultynck \& Jacobs, pl. 9, figs 4, 5, 7, 8 (only).

1989 Ancyrodella binodosa Uyeno. - Sandberg, Ziegler \& Bultynck, p. 209, pl. 1, figs 1, 2, text-fig. 2, fig. 1.

2007 Ancyrodella binodosa Uyeno. - Aboussalam \& Becker, figs 9I, J.

Remarks. - In the original concept of Ad. binodosa (Uyeno, 1967), only specimens with an ornamentation on the upper surface that is confined to just two large nodes, one on each platform lobe, were included. Bultynck \& Jacobs (1981) extended the concept by emphasising the importance of the basal pit size as the main criterion in the distinction with Ad. rotundiloba and by this included in Ad. binodosa specimens with upper platform surfaces covered with numerous large nodes. The latter were included in the early morphotypes of Ad. rotundiloba by Klapper (1985).

In upper view, the figured specimen shows two distinct rounded platform lobes, each one bearing one node. The carina is straight and consists of a row of small distinct denticles. The free blade is straight and consists, besides small denticles, of two markedly larger and higher denticles immediately behind the anteriormost smaller denticle. The basal pit is large and cruciform. The platform lobes are situated just posterior of the midlength of the element. Posterior of the lobes, the platform is very narrow and does not reach the posterior end.

The specimen can be distinguished from Ad. pristina by the shape of the platform that shows two distinct rounded 
platform lobes and differs from the more triangular platform shape of Ad. pristina, by the absence of marginal nodes next to the single large node on each platform half, the absence of small secondary keels and by the larger basal pit.

In the Villech section, Ad. binodosa does not precede Ad. pristina, but its lowest occurrence takes place above the first appearance of $A d$. pristina in sample Vi-I/36A. In sample Vi-I/36 several specimens are found that resemble Ad. binodosa in shape, but do not have any nodes (or at most a slight start of a node) on the platform. Their basal pit extends under the entire element, while in Ad. binodosa, the basal pit is cruciform or T-shaped. These specimens are considered juvenile forms. The smallest forms of most species of Ancyrodella generally have similar morphology. They are mentioned in this study as Ancyrodella binodosa juvenile form. (Fig. 6D, E). Similar forms were figured from Blauer Bruch (Germany) by Sandberg et al. (1989, pl. 1, figs 7,8). A similar form was also illustrated as part of the ontogenetic series 2 of Ancyrodella by Miller (2007, figs $3 \mathrm{U}, \mathrm{V})$. The specimen illustrated in Fig. 6I, J can be seen as a transitional form between Ad. binodosa and Ad. pristina or a more advanced specimen of Ad. binodosa. The specimen still bears the two distinctively rounded platform lobes characteristic for Ad. binodosa but marginal nodes are already present on the platform around the two large nodes and aside of the carina. The basal pit is cruciform and smaller than the one typical for specimens of Ad. binodosa. One lateral keel, which does not reach the platform edge, is developed.

Stratigraphical distribution. - Lower falsiovalis Zone (Sandberg et al. 1989); MN 1 Zone (Aboussalam \& Becker 2007, Narkiewicz \& Bultynck 2011), within the Lower falsiovalis Zone to the base of the punctata Zone (MN 1-4) (Gouwy et al. 2007), within MN 1, 2 zones (Narkiewicz \& Bultynck 2010).

Material. - 4 specimens from sample Vi-I/36.

\section{Ancyrodella pristina Khalymbadzha \& Chernysheva, 1970}

Figure 6L, M

1970 Ancyrodella pristina n. sp.; Khalymbadzha \& Chernysheva, pp. 88, 89, pl. 1, figs 3-8.

1981 Ancyrodella binodosa Uyeno. - Bultynck \& Jacobs, pp. 16, 17, pl. VIII, figs $1-10,13,14$; pl. IX, figs $1-3,6$.

1985 Ancyrodella rotundiloba (Bryant). - Klapper, pl. 1, figs 1-14; pl. 2, figs 1-5, 2-8; pl. 3, figs 7, 8 .

1989 Ancyrodella pristina Khalymbadzha \& Chernysheva. Sandberg, Ziegler \& Bultynck, pp. 210, 211, text- figs $2.2-2.4$, pl. 1, figs $3,4,13,14$ [non figs $9,10=$ Ad. soluta].

2007 Ancyrodella rotundiloba pristina Khalymbadzha \& Chernysheva. - Aboussalam \& Becker, pp. 364, 365, figs 9K, L, O-R.

2007 Ancyrodella pristina Khalymbadzha \& Chernysheva. - Miller, p. 445, figs 2A-2Y.

2008 Ancyrodella pristina Khalymbadzha \& Chernysheva. Liao \& Valenzuela-Ríos, pp. 2, 3, 7, fig. 6J [only].

Remarks. - The concept of Ad. pristina used here follows the definition of the early morphotype of $A d$. rotundiloba by Klapper (1985) and is also according to the interpretation of Aboussalam (2003). The most important features to distinguish this species are the subtriangular platform outline and the size of the basal pit which is about half of the platform width. The Villech population contains simple ontogenetic stages with a slight lanceolate platform shape, very few marginal nodes and two straight anterior platform margins (Fig. 6L, M, Ad. pristina morphotype 2 of Sandberg et al. 1989) and the more advanced ontogenetic stages with more secondary nodes and rounded anterior platform on one side (Ad. pristina morphotype 3 of Sandberg et al. 1989).

Stratigraphical distribution. - MN 1 Zone (Aboussalam \& Becker 2007), within the Lower falsiovalis Zone (Sandberg et al. 1989, Gouwy et al. 2007), MN 1, 2 (Liao \& Valenzuela-Ríos 2008).

Material. - 17 specimens in samples Vi-I/36A (1 cf.), Vi-I/36 (16).

\section{Ancyrodella rotundiloba (Bryant, 1921)}

Figure 6P, Q

1921 Polygnathus rotundilobus sp. nov.; Bryant, pp. 26, 27, pl. 12, figs 1-6.

1980 Ancyrodella rotundiloba rotundiloba (Bryant). Bultynck \& Hollard, p. 38, pl. 10, fig. 7.

1981 Ancyrodella binodosa Uyeno. - Bultynck \& Jacobs, pp. 16, 17, pl. VIII, figs 11, 12.

1981 Ancyrodella rotundiloba rotundiloba (Bryant). Bultynck \& Jacobs, pp. 17, 18, pl. X, figs 5, 8, 9.

1985 Ancyrodella rotundiloba (Bryant). - Klapper, pp. 24-27, pl. 1, figs 15-20; pl. 2, figs 9-12; pl. 3, figs 5, 6; pl. 4, figs 9-12.

1989 Ancyrodella soluta n. sp. - Sandberg, Ziegler \& Bultynck, pp. 211, 212, pl. 1, figs 5, 6; pl. 2, figs 1-4; text-fig. 2, figs 5-7.

1994 Ancyrodella rotundiloba (Bryant). - Kralick, figs 3.21 to 3.24 .

2007 Ancyrodella rotundiloba soluta Sandberg, Ziegler \& Bultynck. - Aboussalam, p. 364. 
2007 Ancyrodella rotundiloba (Bryant). - Miller, pp. 445, 446, figs 3A-G, 3K-P, S-V.

2008 Ancyrodella soluta Sandberg, Ziegler \& Bultynck. Liao \& Valenzuela-Ríos, p. 7, figs 6K-P.

Remarks. - The figured specimen shows a lanceolate to triangular shaped platform ornamented with nodes. Two slightly larger nodes are situated in the middle part of the anterior half of the platform, one on each side of the carina. They are surrounded by marginal nodes and nodes situated in between the two larger nodes and the marginal nodes. On the lower platform side, the basal pit is rather small and cruciform. Small keels are developed as extensions of the pit, but do not reach the platform margins.

The taxonomy of the early ancyrodellids has been the topic of many discussions in the last few decades, especially when it concerns the validity of the Ad. soluta species. The authors here follow the opinion of Kralick (1994), Klapper (2000) and Miller (2007) in that Ad. soluta is not a valid species. Most of the original type specimen of Sandberg et al. (1989) cannot be distinguished from Ad. pristina and the holotype itself is a good representative of Ad. rotundiloba s.s. (late form of Klapper 1985). Kralick (1994) and Klapper (2000) suggested that Ad. soluta and Ad. pristina are not sufficiently distinguishable from each other to exist as separate species. Miller (2007) studied the ontogenetic series of early ancyrodellids amongst which Ad. pristina and Ad. rotundiloba and concluded that, after comparing several morphological trends, that the platform width to basal pit width ratio and platform shape are not such good criteria to distinguish between the species since they are observed to change within the ontogenetic series of both species. Ancyrodella rotundiloba s.s. is distinguished from Ad. pristina by more and denser nodes on the platform (one to several nodes inserted between the marginal nodes and the carina). The figured specimen Fig. 6N, O is a more evolved form of Ad. pristina compared to Fig. 6L, M (more platform nodes and smaller basal pit) and can be a transitional form with Ad. rotundiloba s.s. based on the platform ornamentation. Only two specimens of Ad. rotundiloba s.s. have been recovered, both found in sample Vi-I/36.

Stratigraphical distribution. - From within the Lower falsiovalis Zone till into the transitans Zone (Sandberg et al. 1989; MN 1-4).

Material. - 2 specimens in sample Vi-I/36.

\section{Genus Klapperina Lane, Müller \& Ziegler, 1979}

Type species. - Klapperina disparalvea (Orr \& Klapper, 1968).
Klapperina cf. K. disparalvea (Orr \& Klapper, 1968) Figure 5O, P

1968 Palmatolepis? disparalvea n. sp.; Orr \& Klapper, pl. 140, fig. 1-11.

1976 Palmatolepis disparalvea Orr \& Klapper. - Ziegler, Klapper \& Johnson, p. 119, pl. 1, fig. 23.

1980 Palmatolepis disparalvea Orr \& Klapper. - Bultynck \& Hollard, p. 41, pl. VIII, figs 20a, b.

2007 Klapperina disparalvea (Orr \& Klapper). - Over, figs $10.21-10.22$.

Remarks. - The figured specimen has the characteristic asymmetric platform with a broad outer lobe, located anterior to the position of the distinctive central node and delimited by a faint anterior sinus. A posterior sinus is not visible since the platform margin is missing in that position. The platform surface is covered with rather coarse irregularly placed nodes. The broad L-shaped basal pit is large, shallow and situated in the posterior half of the platform, covering $3 / 4$ of the posterior platform length.

$K$. disparalvea can be distinguished from $K$. disparilis by the presence of a well-differentiated outer platform lobe, a larger basal pit and the coarser nodes on the upper platform.

Stratigraphical distribution. - The species first occurs at the base of the disparilis Zone and ranges up to the top of the norrisi Zone (Aboussalam 2003).

Material. - 2 specimens from samples Vi-I/34A (1aff), Vi-I/ 35 (1cf).

Klapperina cf. K. disparilis (Ziegler \& Klapper, 1976) Figure 5S, T

1976 Palmatolepis disparilis n. sp.; Ziegler, Klapper \& Johnson, p. 119, pl. 1, figs 18-22, 24-31.

1982 Palmatolepis disparilis Ziegler \& Klapper. - Ziegler \& Klapper, p. 467, pl. 3, figs 5, 7-15.

2003 Klapperina disparilis Ziegler \& Klapper. - Aboussalam, p. 170, pl. 19, figs 13-14.

2007 Klapperina disparilis Ziegler \& Klapper. - Aboussalam \& Becker, fig. 9e.

2008 Klapperina disparilis Ziegler \& Klapper. - Liao \& Valenzuela-Ríos, p. 8, figs 5K, L (transitional form between $P$. cristatus and $K$. disparilis), 5Q, R.

Remarks. - Only the posterior half of the platform, carrying the basal pit and part of the anterior half of the platform were preserved from the specimen found in sample $\mathrm{Vi}-\mathrm{I} / 34$. The preserved part has an oval-shaped platform margin without lobe and bears moderate size nodes in a 
chaotic arrangement on its upper side. The central node is not markedly larger than the nodes of the posterior part of the carina. The carina does not reach the posterior tip of the platform. A medium size L-shaped basal pit is developed on the lower side of the platform, covering slightly less than half of the posterior platform length.

The broken specimen in sample Q-1/2 (Fig. 5M, N) shows a rather straight carina with large central node and moderate sized nodes on the upper platform. The carina does not reach the posterior end. The basal pit is large and L-shaped. Part of the basal plate is still attached to the lower surface. Although the specimen is broken, an initiation of a platform lobe can be seen on the lower view. A weak sinus in the platform margin is situated immediately posterior of the missing part. Showing characteristics of $K$. disparalvea (large L-shaped basal pit and large central node) but missing a well-developed outer platform lobe, this specimen can be seen as transitional between $K$. disparilis and $K$. disparalvea.

The species differs from $K$. disparata by the distinct $\mathrm{L}$-shape of the basal pit in the former.

Stratigraphical distribution. - The species defines the base of the disparilis Zone (Klapper \& Johnson 1990) and its range is restricted to this Zone (Narkiewicz \& Bultynck 2010).

Material. - 2 specimens from samples Vi-I/ 34 (1), Q-1/2 (1).

\section{Genus Ozarkodina Branson \& Mehl, 1933}

Type species. - Ozarkodina typica Branson \& Mehl, 1933.

\section{“Ozarkodina” brevis (Bischoff \& Ziegler, 1957)}

Figure 4P

1957 Spathognathus brevis n. sp.; Bischoff \& Ziegler, p. 116, pl. 19, figs $24,27-29$.

1976 Ozarkodina brevis (Bischoff \& Ziegler). - Ziegler et al., pl. 3, figs 14-16.

1985 Ozarkodina brevis (Bischoff \& Ziegler). - Olivieri, pl. 2, figs 9-11.

2003 Ozarkodina brevis (Bischoff \& Ziegler). - Aboussalam, p. 171, pl. 28, fig. 18.

Remarks. - The figured specimen is an "Ozarkodina" species with a short denticulated (11 denticles) blade. The blade is two times as long as it is high with a small deep rectangular-shaped basal cavity covering the posterior third of the blade and situated at its posterior end. The denticles of the blade (partially fused at their bases) are of equal size and height in the middle part of the blade and decline in height to the anterior end. The posteriormost denticle is the broadest and is slightly inclined posteriorward.

Stratigraphical distribution. - The species is found from the upper part of the Lower varcus Zone (Weddige 1977) till up to the norrisi Zone (Klapper in Ziegler 1977).

Material. - 2 specimens in sample Vi-I/26.

\section{“Ozarkodina” sannemanni proxima Pollock, 1968} Figure 5H

1968 Spathognathodus sannemanni proxima n. subsp.; Pollock, pp. 439, 440, pl. 63, figs 8, 9, 12, 13, 18, 19.

2003 Ozarkodina sannemanni proxima Pollock. - Aboussalam, p. 173, pl. 24, figs 11, 12.

2007 Ozarkodina sannemanni proxima Pollock. - Aboussalam \& Becker, fig. 8P.

Remarks. - The figured specimen has a distinct outward bended anterior part of the blade. The denticles on the blade, partially fused at their bases, are larger on the anterior part of the blade. The basal cavity, situated in the posterior middle part of the blade, shows two lateral platform-like rounded expansions of which the inner one is only weakly developed and has a smooth upper surface. The outer lateral expansion carries one large node. The specimen can be distinguished from "O." sannemanni sannemanni by the only weak development of the inner lateral expansion of the basal cavity and by the presence of only one node on only the outer lateral expansion. "O." sannemanni sannemanni is characterised by at least one node on both well-developed lateral expansions.

Stratigraphical distribution. - The species appears at the base of the hermanni Zone and goes up into the transitans Zone (Pollock 1968). In the Villech section the species has been found in the norrisi Zone.

Material. - 2 specimens in sample Vi-I/35.

“Ozarkodina” semialternans (Wirth, 1967)

Figure 4Q

1967 Spathognathodus semialternans n. sp.; Wirth, text-figs 14a, b, pl. 23, figs 6-10.

1976 Ozarkodina semialternans (Wirth). - Ziegler, Klapper \& Johnson, pp. 118, 119, pl. 3, figs 22-24.

1980 Polygnathus semialternans (Wirth). - Bultynck \& Hollard, p. 45, pl. VIII, figs 5, 6.

1987 Polygnathus semialternans (Wirth). - Bultynck, p. 162. 
2003 Ozarkodina semialternans (Wirth). - Aboussalam, pp. 173, 174, pl. 24, figs $1-7$.

Remarks. - The figured specimen has a long blade, with anterior denticles that are somewhat broader than the posterior ones. An alternation of broad and narrower denticles is present only in the middle part of the blade immediately anterior of the basal cavity. This feature is mentioned in the revised description of Ziegler et al. (1976) as possibly present in the anterior part of the blade but usually absent in larger specimens. Some of the specimens illustrated by Aboussalam (2003) lack this alternation.

The denticles of the figured specimen decrease in height in the posterior third of the blade. The basal cavity is situated in the posterior third of the unit. The anterior lower margin of the blade is convex, is slightly turning upwards under the basal cavity and is bending down again behind the cavity in the posterior part of the blade.

Stratigraphical distribution. - The species first appears in the uppermost part of the Middle varcus Zone and goes up into the norrisi Zone (Norris \& Uyeno 1982, Aboussalam 2003). The species defines the base of the semialternans/latifossatus Zone (Bultynck 1987).

Material. - 2 specimens from samples Vi-I/26 (1), Vi-I/34 (1).

\section{Genus Polygnathus Hinde, 1879}

Type species. - Polygnathus dubius Hinde, 1879.

\section{Polygnathus angusticostatus Wittekindt, 1966 Figure 4N}

1966 Polygnathus angusticostata n. sp.; Wittekindt, p. 631, pl. 1, figs 15-18.

1971 Polygnathus angusticostatus Wittekindt. - Klapper, p. 65 , pl. 3, figs 21-25.

1980 Polygnathus angusticostatus Wittekindt. - Bultynck \& Hollard, p. 41, pl. 3, figs 10a, b, 17.
1988 Polygnathus angusticostatus Wittekindt. - Sparling, fig. 15.6.

Remarks. - The figured specimen has a small platform with short transverse ridges separated from the carina by wide adcarinal grooves. The small platform is triangular. The platform margins are subparallel to the carina in the anterior part of the platform. The carina extends posterior of the platform by two nodes. The pit is located between the midlength and the anterior end of the platform and is of moderate size.

The species can be distinguished form $P$. robusticostatus by its posterior extension of the carina beyond the platform.

Stratigraphical distribution. - The species appears at the base of the costatus Zone (Belka et al. 1997) and the upper part of the zone in the Ardennes and the Eifel area (Weddige 1977). It ranges up to the base of the ensensis Zone in the Anti-Atlas (Belka et al. 1997) and to the lower part of the hemiansatus Zone in the Ardennes (Gouwy \& Bultynck 2003).

Material. - 5 specimens from samples Vi-I/5 (2), Vi-I/17t (1), V502 (2).

Polygnathus angustipennatus Bischoff \& Ziegler, 1957 Figure 4M

1957 Polygnathus angustipennatus n. sp.; Bischoff \& Ziegler, p. 85, pl. 2, fig. 16; pl. 3, figs 1-3.

1971 Polygnathus angustipennatus Bischoff \& Ziegler. Klapper, p. 65, pl. 3, fig. 27.

1980 Polygnathus angustipennatus Bischoff \& Ziegler. Bultynck \& Hollard, p. 41, pl. 3, figs 9a, b.

1987 Polygnathus angustipennatus Bischoff \& Ziegler. Bultynck, pl. 9, fig. 15.

1988 Polygnathus angustipennatus Bischoff \& Ziegler. Sparling, fig. 15.5 .

Remarks. - The figured specimen shows a small platform that occupies one third of the total length of the unit. The

Figure 4. A - Polygnathus sp. A, upper view, Vi-I/8 MGUV6002, $\times 80$. B - Polygnathus partitus Klapper, Ziegler \& Mashkova, 1978, upper view, Vi-I/8 MGUV6003, $\times 63$. C C D - Polygnathus costatus Klapper, 1971, upper views, 3: Vi-I/3, MGUV6004, × 37; 4: Vi-I/5, MGUV6005, × 42. -E - Polygnathus pseudofoliatus Wittekindt, 1966, $\alpha$ morphotype Walliser \& Bultynck, 2011, upper view, Vi-I/18 MGUV6011, × 41. • F, G - Tortodus cf. T. kockelianus kockelianus (Bischoff \& Ziegler, 1957), upper and lower views, Vi-I/15 MGUV6006, $\times 61 . \bullet \mathrm{H}-$ Polygnathus pseudoeiflius Walliser \& Bultynck, 2011, upper view, Vi-I/20 MGUV6012, × 57. • I - Polygnathus eiflius Bischoff \& Ziegler, 1957, upper view, Vi-I/19 MGUV6015, ×59. • J - Polygnathus hemiansatus Bultynck, 1987, upper view, Vi-I/18 MGUV6016, × 56. $\bullet \mathrm{K}-$ Polygnathus aff. P. ansatus Ziegler \& Klapper, 1976, upper view, Vi-I/32 MGUV6014, × 54. $\bullet$ L - Polygnathus denisbriceae Bultynck, 1979, upper view, Vi-I/25 MGUV6013, $\times 37$. - M - Polygnathus angustipennatus Bischoff \& Ziegler, 1957, upper view, V500 MGUV6001, $\times 80 . \bullet \mathrm{N}-$ Polygnathus angusticostatus Wittekindt, 1966, upper view, Vi-I/5 MGUV6022, × 58. • O - Polygnathus ensensis Ziegler \& Klapper, 1976; upper view, Vi-I/18, MGUV6021, × 67. -P - "Ozarkodina" brevis (Bischoff \& Ziegler, 1957), lateral view, Vi-I/26 MGUV6017, × 100. • Q - "Ozarkodina" semialternans (Wirth, 1967), lateral view, Vi-I/34 MGUV6019, × 75 . 

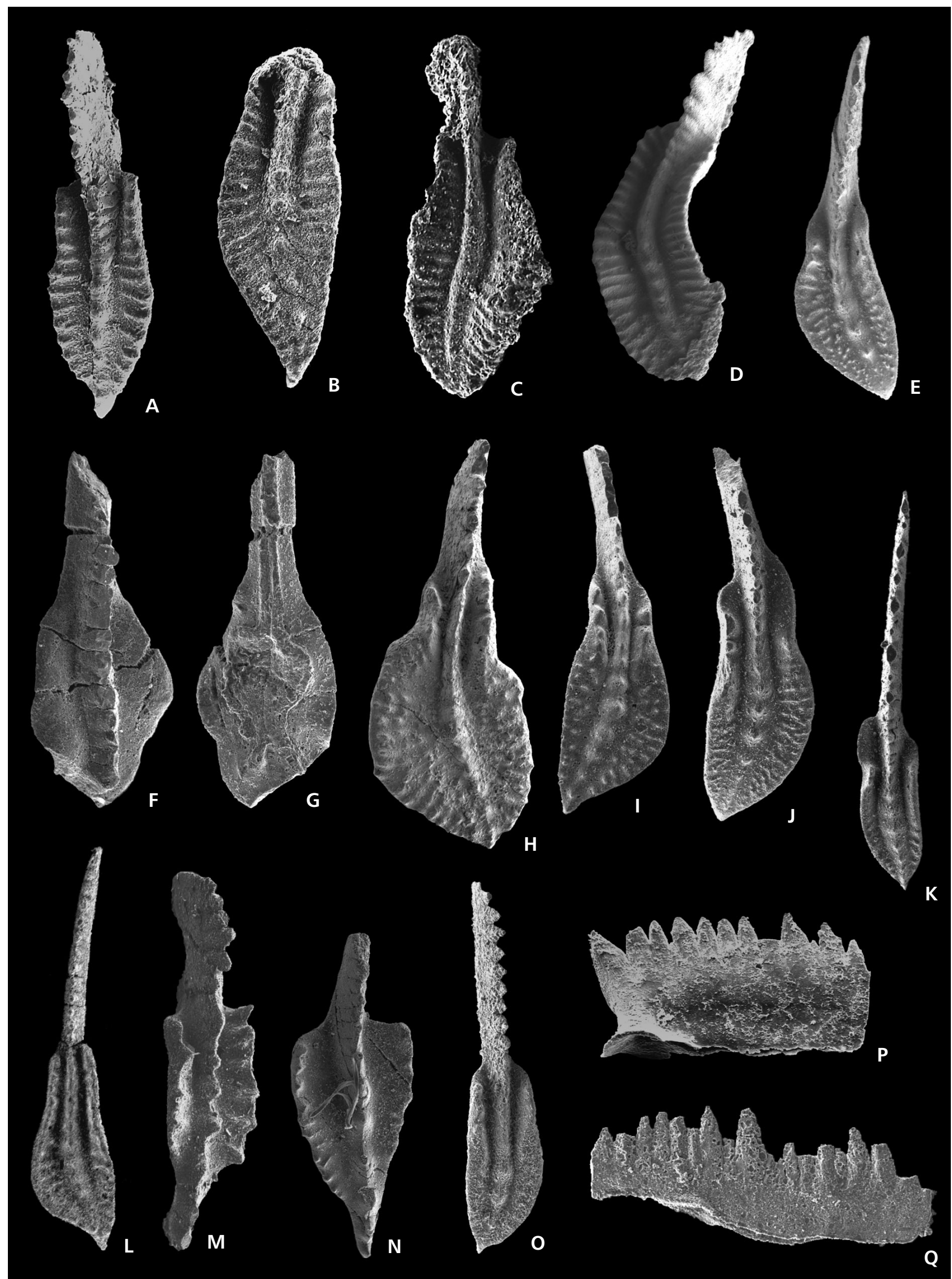
high platform margins are more or less parallel and are ornamented with strong marginal ridges. The carina extends beyond the platform by three carina denticles.

$P$. angustipennatus can be distinguished from $P$. angusticostatus by the more restricted platform development and a longer and higher free blade.

Stratigraphical distribution. - The species appears from the lowermost part of the costatus Zone (Belka et al. 1997). Bultynck \& Hollard (1980) report a $P$. aff. P. angustipennatus from the upper part of the partitus Zone. P. angustipennatus ranges up till the lowermost part of the hemiansatus Zone (Bultynck 1987, Gouwy \& Bultynck 2002).

Material. - 1 specimen from samples V 500.

\section{Polygnathus aff. P. ansatus Ziegler \& Klapper, 1976 Figures 4K, 5F}

Remarks. - Both figured specimens show a long, slender and slightly sideward bowed platform ornamented with thin transverse ridges separated from the carina by adcarinal grooves. The wide carina reaches the posterior tip and continues slightly beyond the margins of the platform. Both anterior trough margins are bowed; the inner one only slightly. The small basal pit is situated in the anterior part of the platform. Both specimens resemble P. ansatus in the bowing of the anterior through margins but are distinguished from the typical specimens by the broader carina consisting of almost completely fused nodes, the somewhat wider platform and the less deep adcarinal grooves. Moreover, the Fig. $4 \mathrm{~K}$ specimen differs from $P$. ansatus by the anterior ends of the anterior through margins meeting the blade at different positions; the Fig. 5F specimen differs by the non-opposite geniculation points.

Stratigraphical distribution. - Base of the disparilis Zone.

Material. - 2 specimens from samples Q-1/2 (1) and Vi-I/32 (1).

\section{Polygnathus costatus Klapper, 1971}

Figure 4C, D

1971 Polygnathus costatus costatus subsp. nov. - Klapper, p. 63, pl. 1, figs 30-36; pl. 2, figs 1-7.

1978 Polygnathus costatus costatus Klapper. - Klapper et al., pl. 2, figs ?10, ?11, 12 .

1983 Polygnathus costatus costatus Klapper. - Sparling, pl. 10, figs AB, AC; pl. 11, figs AB, AC, AF, AG.

1985 Polygnathus costatus costatus Klapper. - Bultynck, p. 270, pl. 8, figs 13-17.
2009 Polygnathus costatus costatus Klapper. - Berkyová, pp. 676, 678, pl. 6I-L.

2011 Polygnathus costatus Klapper. - Vodrážková, Klapper \& Murphy, p. 742, figs 6A-I, K, L.

Remarks. - Specimens have a platform with an outer platform side that is slightly wider than the inner platform side. The platform is curved, long and narrow. The anterior platform margins are constricted, the platform is widest in its posterior third. The platform is ornamented with thin, long, densely spaced ridges, separated from the carina by deep, narrow grooves. The grooves become less deep, but are still narrow, closer to the posterior end of the platform. The carina reaches the posterior end. The pit is situated more or less at the first third of the platform.

$P$. costatus can be distinguished from $P$. patulus and $P$. partitus by the width of the platform, which is largest in its posterior third. The platform bears more densely spaced transverse ridges compared with the other two subspecies. $P$. costatus has a more constricted anterior platform than $P$. patulus and has more rounded posterior margins compared to $P$. partitus.

Stratigraphical distribution. - The first appearence of the species defines the base of the costatus Zone. Polygnathus costatus ranges up till halfway the australis Zone in Morocco (Belka et al. 1997) and up to the kockelianus Zone in the Eifel region (Weddige 1977).

Material. - 16 specimens from samples $\mathrm{Vi}-\mathrm{I} / 3$ (2), Vi-I/5 (9), Vi-I/6 (2), Vi-I/8A (2), Vi-I/12 (1).

\section{Polygnathus cf. $P$. cristatus cristatus Hinde, 1879} Figure 5Q, R

1879 Polygnathus cristatan. sp.; Hinde, p. 366, pl. 7, fig. 11.

2008 Polygnathus cristatus cristatus Hinde. - Liao \& Valenzuela-Ríos, pp. 8, 9, figs 5M, N.

Remarks. - The specimen found in sample Q-1/2 is fragmentary. The fragment is rather thick and is ornamented with coarse nodes that are arranged in rows parallel to the carina. The platform is broken right through the basal pit.

The specimen fragment differs from specimens of $K$. disparilis or $P$. cristatus ectypus by the orderly arranged platform nodes. Aboussalam \& Becker (2007) restrict the definition of the subspecies and assign only specimens with partly fused platform nodes to it.

Stratigraphical and geographical distribution. - The subspecies has it first appearance in the hermanni Zone and ranges up within the Upper disparilis Zone (Klapper \& Johnson 1990). 
Material. - One specimen from sample Q-1/2.

\section{Polygnathus aff. P. dengleri sagitta Aboussalam \& Becker, 2007}

Figure 6B, C

Remarks. - The figured specimen does not show the typical subtriangular, sagittate platform but a subtriangular to somewhat oval shaped platform ornamented by strong transverse ridges that are separated from the carina by shallow adcarinal grooves. The short free blade consists of a few fused denticles. The anterior part of the carina is straight and formed by fused nodes; the posterior carina is formed by slightly merged nodes and reaches the pointed tip of the platform. The small basal pit is elongated and is located in the middle of the anterior half of the platform. The keel is slightly curved.

The specimen differs from $P$. dengleri dengleri by the shape of the platform and the more anterior position of the basal pit.

Stratigraphical distribution. - From the base of the dengleri sagitta Subzone (Aboussalam \& Becker 2007) up to MN 3.

Material. - 1 specimen in sample Vi-I/34.

\section{Polygnathus eiflius Bischoff \& Ziegler, 1957 Figure 4I}

1957 Polygnathus eiflia n. sp.; Bischoff \& Ziegler, pp. 89, 90, pl. 4, figs 5-7.

1977 Polygnathus eiflius Bischoff \& Ziegler. - Weddige, p. 311, pl. 4, fig. 66 .

2001 Polygnathus eiflius Bischoff \& Ziegler. - Liao et al., pp. 27, 28, pl. 3, figs 6, 8-9, 13.

2011 Polygnathus eiflius Bischoff \& Ziegler. - Walliser \& Bultynck, p. 11, pl. 1, fig. 6.

Remarks. - The modified description by Walliser \& Bultynck (2011) is followed here, indicating P. eiflius by a platform with the typical short anterior symmetric rostrum with relatively high and mostly serrated margins that continue as diagonal ridges or rows of nodes. The platform is widest in the posterior half and shows a distinct convex curve in the outer platform margin. The inner platform margin is only slightly curved. The platform is ornamented with small rounded or elongated nodes.

Stratigraphical distribution. - The species ranges from the base of the eiflius Zone up to within the lower part of the $t i$ morensis Zone (Walliser \& Bultynck 2011).
Material. - 26 specimens from samples Vi-I/17 (3), $\mathrm{Vi-}-\mathrm{I} / 17 \mathrm{t}$ (1), Vi-I/18A (3), Vi-I/18 (1), Vi-I/19 (1), Vi-I/20 (14), Vi-I/21 (1), V502 (2).

\section{Polygnathus ensensis Ziegler \& Klapper, 1976} Figures 4O, 5A (aff.)

1976 Polygnathus xylus ensensis n. sp.; Ziegler \& Klapper, pp. 125-127, pl. 3, figs 4-9.

1987 Polygnathus ensensis Ziegler \& Klapper. - Bultynck, p. 161, pl. 7, figs 1-6.

1989 Polygnathus ensensis Ziegler \& Klapper. - Bultynck, pp. 97-99, pl. 2, figs 12-21.

2001 Polygnathus xylus ensensis Ziegler \& Klapper. - Liao et al., p. 40, pl. 3, fig. 23.

Remarks. - The figured specimen has distinctly serrated anterior platform margins, straight to steeply downward declined anterior trough margins joining the free blade at the same position and a posteriorly down-arched platform. The platform surface is smooth and has deep adcarinal troughs in the anterior part and shallow troughs in the posterior part. In lateral view the platform is down-arched (not figured). Polygnathus aff. P. ensensis in Fig. 5A, misses the down-arching of the platform typical for P. ensensis specimens but shows serrations on the inner anterior platform margin.

Polygnathus ensensis can be distinguished from P. xylus by the distinctly serrated anterior platform margins and the distinctly down-arched posterior platform.

Stratigraphical distribution. - P. ensensis ranges from the base of the ensensis Zone up to the uppermost part of the Middle varcus Zone (Liao \& Valenzuela-Ríos 2008).

Material. - 21 specimens from samples Vi-I/18A (3), Vi-I/18 (5), Vi-I/19 (7), Vi-I/20 (3), Vi-I/21 (1), Vi-I/23A (1), Vi-I/26 (1 aff.).

\section{Polygnathus hemiansatus Bultynck, 1987}

Figure 4J

1980 Polygnathus aff. P. ansatus Ziegler \& Klapper. - Bultynck \& Hollard, p. 42, pl. 5, fig. 18; pl. 6, figs 2-4.

1985 Polygnathus ansatus Ziegler \& Klapper. - Bultynck, p. 269, pl. 6, figs 19, 20.

1987 Polygnathus hemiansatus n. sp.; Bultynck, pp. 161, 162, pl. 7, figs 16-27; pl. 8, figs 1-7.

2008 Polygnathus hemiansatus Bultynck. - Liao \& Valenzuela-Ríos, figs 4A, B.

2011 Polygnathus hemiansatus Bultynck - Walliser \& Bultynck, p. 12, pl. 1, figs 11-17. 
Remarks. - The figured specimen shows the main characteristic of $P$. hemiansatus: outward bowing of the outer anterior trough margin, a straight inner anterior platform margin, a strong constriction posterior of the outer geniculation point. The inner anterior platform margin is serrated. The platform is ornamented with small nodes and small interrupted ridges. This specimen belongs to the $\beta$ morphotype of Walliser \& Bultynck (2011).

The species is distinguished from $P$. ansatus by the straight inner platform margin instead of the outward bowing of the inner margin in the latter. It is different from $P$. timorensis in the wider shape of the posterior platform and the shallow adcarinal grooves of the former.

Stratigraphical distribution. - The species defines the base of the hemiansatus Zone and ranges into the ansatus Zone (Walliser \& Bultynck 2011).

Material. - 15 specimens from samples Vi-I/18A (4), Vi-I/18 (6), V1/2 (3), Vi-I/23A (1), Vi-I/28 (1).

\section{Polygnathus partitus Klapper, Ziegler \& Mashkova, 1978}

Figure 4B

1978 Polygnathus costatus partitus subsp. nov.; Klapper et al., p. 109, pl. 2, figs 1-5, 13.

1985 Polygnathus costatus partitus Klapper, Ziegler \& Mashkova. - Bultynck, p. 270, pl. 8, figs 19, 20.

1999 Polygnathus costatus partitus Klapper, Ziegler \& Mashkova. - Gouwy et al., pl. 1, fig. 6, table.

2009 Polygnathus costatus partitus Klapper, Ziegler \& Mashkova. - Berkyová, pp. 675, 676, figs 5D-I.

Remarks. - Specimen has a slender, narrow, suboval platform with an outer platform that is slightly larger than the inner platform. The anterior platform margins are constricted. The inner and outer posterior margins tend to be straight and meet the posterior end of the platform to form a sagittate outline. The upper platform bears narrow, long trans- verse ridges separated from the carina by adcarinal grooves that are relatively deep in the anterior part of the platform and shallow to flat in the posterior half. In some specimens the tip is slightly curved.

Polygnathus partitus can be distinguished from $P$. costatus by the wider platform at midlength, the straight inner and outer posterior margins, converging to form a sagittate outline, the less constricted or parallel anterior trough margins and less the densely spaced transverse ridges as ornamentation on the platform surface.

Stratigraphical distribution. - The first appearance of the species indicates the base of the partitus Zone. The species ranges up into the costatus Zone (Belka et al. 1997).

Material. - 7 specimens from samples Vi-I/2 (1), Vi-I/3A (2), Vi-I/4 (1), V501 (1), Vi-I/8 (1), Vi-I/10 (1).

Polygnathus pseudoeiflius Walliser \& Bultynck, 2011 Figure $4 \mathrm{H}$

2010 Polygnathus aff. P. eiflius Bischoff \& Ziegler. Gouwy, p. 141, pl. 5, fig. 6 .

2011 Polygnathus pseudoeiflius n. sp.; Walliser \& Bultynck, p. 11, pl. 1, figs 3-5.

Remarks. - The specimen shows strongly constricted parallel anterior platform margins and a posterior outer and inner platform expansion in a strong convex curve. The inner anterior margin is serrated. The platform is ornamented with small nodes.

The specimen lacks the diagonal rostral ridges that are typical for P. eiflius.

Stratigraphical distribution. - Walliser \& Bultynck (2011) situate the species from within the kockelianus Zone up to within the timorensis Zone. It if found in the lower part of the ansatus Zone in the Villech section.

Material. - 1 specimen from sample Vi-I/20.

Figure 5. A - Polygnathus aff. P. ensensis Ziegler \& Klapper, 1976, upper view, Vi-I/26 MGUV6027, × 65. • B, C - Tortodus caelatus (Bryant, 1921), upper and lower views, Vi-I/30 MGUV6028, × 45. D - Tortodus aff. T. schultzei Aboussalam, 2003, upper view, Vi-I/29 MGUV6029, $\times 49$. -E - Tortodus bultyncki Aboussalam, 2003, upper view, Vi-I/33A MGUV6030, × 45. • F - Polygnathus aff. P. ansatus Ziegler \& Klapper, 1976; upper view, Q-1/2, MGUV6023, × 24. • G - Schmidtognathus pietzneri Ziegler, 1966, upper view, Vi-I/33 MGUV6037, ×63. $\bullet$ H - Ozarkodina sannemanni proxima Pollock, 1968, upper view, Vi-I/35 MGUV6038, × 62.・I - Polygnathus cf. P. tafilensis Aboussalam \& Becker, 2007, upper view, Vi-I/33 MGUV6036, $\times$ 57. • J - Schmidtognathus wittekindti Ziegler, 1966, upper view, Vi-I/35 MGUV6039, × 65. $・$ K, L - Schmidtognathus aff. Schm. hermanni Ziegler, 1965, lower and upper views, Vi-I/33 MGUV6041, × 52. • M, N - transitional form between Klapperina disparilis (Ziegler \& Klapper, 1976) and Klapperina disparalvea (Orr \& Klapper, 1968), upper and lower views, Q-1/2, MGUV6035, × 44. • O, P - Klapperina cf. K. disparalvea (Orr \& Klapper, 1968), upper and lower views, Vi-I/35 MGUV6032, ×56. $\bullet$ Q, R - Polygnathus cf. P. cristatus cristatus Hinde, 1879; upper and lower views, Q-1/2, MGUV6034, $\times$ 44. $・$ S, T - Klapperina $\mathrm{cf}$. K. disparilis (Ziegler \& Klapper, 1976), upper and lower views, Vi-I/34 MGUV6033, × 37 . 


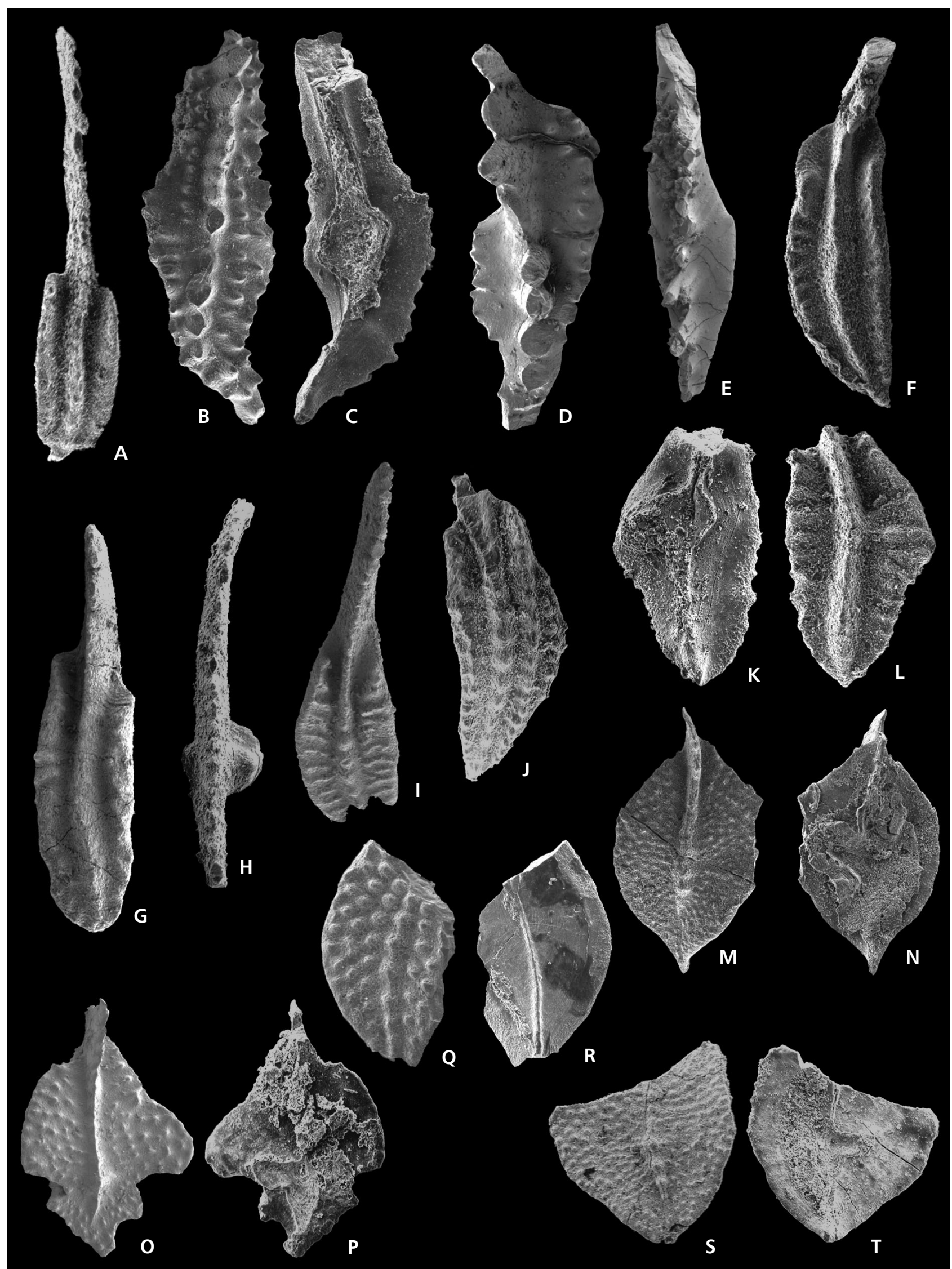




\section{Polygnathus pseudofoliatus Wittekindt, 1966, $\alpha$ morphotype Walliser \& Bultynck, 2011 Figure 4E}

1966 Polygnathus pseudofoliatus n. sp.; Wittekindt, pp. 637, 638, pl. 2, figs 19-23.

2011 Polygnathus pseudofoliatus Wittekindt, morphotype $\alpha$. - Walliser \& Bultynck, p. 11, pl. 1, figs 1, 2.

Remarks. - The figured specimen has a slightly asymmetric platform that is constricted anteriorly (more constriction on the outer anterior side) and is covered with transverse ridges and small nodes, separated from the carina by adcarinal grooves. The platform is widest near its midlength. The inner anterior platform margin bears some small marginal nodes. The free blade is slightly less than $1 / 2$ of the total length of the unit.

The species differs from $P$. eiflius by the absence of diagonal rostral ridges, and from $P$. pseudoeiflius by the greater constriction of the anterior platform in the latter. The $\alpha$ morphotype is distinguished from the $\beta$ morphotype by its less distinct rostrum and broader platform with a predominant ornamentation of small nodes and irregular ribs.

Stratigraphical distribution. - P. pseudofoliatus morphotype $\alpha$ ranges from within the kockelainus Zone to the ansatus Zone (Walliser \& Bultynck 2011).

Material. - 14 specimens from samples Vi-I/15 (2), Vi-I/17t (1), Vi-I/18A (8), Vi-I/18 (1), V1/2 (2).

\section{Polygnathus cf. P. tafilensis Aboussalam \& Becker, 2007}

Figure 5I

2007 Polygnathus tafilensis n. sp.; Aboussalam \& Becker, p. 370 , figs $5 \mathrm{P}-\mathrm{T}$.

Remarks. - The specimen has an asymmetric, flat platform ornamented with transverse ridges that almost touch the carina, separated by very narrow anteriorly situated adcarinal grooves. The platform is widest in the anterior half. The free blade seems shorter than the platform (posteriormost part of the platform is missing). The posterior tip of the specimen is broken. The platform is constricted anteriorly.

The specimen differs from $P$. pennatus by having weaker ribs.

Stratigraphical distribution. - The dengeri to MN1 zones in the Anti-Atlas (Aboussalam \& Becker 2007).

Material. - One specimen from sample Vi-I/33.

\section{Polygnathus sp. A}

Figure 4A

Remarks. - The specimens show an almost symmetrical short and broad platform bearing rather coarse transverse ribs separated from the carina by rather deep and narrow adcarinal grooves. They are deeper anteriorly and flatten posteriorly. The platform margins are slightly constricted in the anterior half of the platform. The platform is widest near midlength. The posterior margins are slightly curved, reaching the carina anterior of the posteriormost denticle. The short free blade is high and consists of narrow partially fused denticles. The straight carina reaches the tip of the platform and continues with one denticle beyond the platform margin.

Stratigraphical distribution. - Both specimens are found in the costatus Zone.

Material. - 2 specimens from samples Vi-I/8 (2).

\section{Genus Schmidtognathus Ziegler, 1966}

Type species. - Schmidtognathus hermanni Ziegler, 1966.

\section{Schmidtognathus aff. Schmidtognathus hermanni Ziegler, 1966}

Figure 5K, L

1966 Schmidtognathus hermanni n. sp.; Ziegler, pp. 664, 665, pl. 3, figs 5-26.

1973 Schmidtognathus hermanni Ziegler. - Ziegler, Catalogue of conodonts, vol. 1, pp. 425, 426, Schmidtognathus, pl. 1, fig. 3 .

Figure 6. A - Mesotaxis falsiovalis-ovalis, upper view, Vi-I/36A MGUV6040, $\times 34 . \bullet \mathrm{B}, \mathrm{C}-$ Polygnathus aff. P. dengleri sagitta Aboussalam \& Becker, 2007, upper and lower views, Vi-I/34 MGUV6043, × 45. D , E - Ancyrodella binodosa; upper view of juvenile specimen MGUV6050, $\times 76$ and lower view of juvenile specimen MGUV6052; Vi-I/36, × 77. • F, G - Ancyrodella binodosa Uyeno, 1967, upper and lower views, Vi-I/36 MGUV6049, × 65 . $\cdot \mathrm{H}, \mathrm{K}$ - Skeletognathus norrisi (Uyeno, 1967); H - upper-lateral view of Pa-element MGUV6048, × 91; K - lateral view of Pb-element, MGUV6051, × 73, Vi-I/35. • I, J - transitional form between Ancyrodella binodosa Uyeno, 1967 and Ancyrodella pristina Khalymbadzha \& Chernysheva, 1970; upper and lower views; Vi-I/36, MGUV6046, ×36. • L, M-Ancyrodella pristina Khalymbadzha \& Chernysheva, 1970, morphotype 2 of Sandberg et al. (1989); upper and lower views, Vi-I/36 MGUV6047, $\times 52 \cdot \bullet \mathrm{N}, \mathrm{O}-$ Ancyrodella pristina, transitional form with Ad. rotundiloba (Bryant, 1921), upper and lower views, Vi-I/36 MGUV6045, × 43. P P, Q-Ancyrodella rotundiloba (Bryant, 1921), late form of Klapper (1985), upper and lower views, Vi-I/36 MGUV6044, × 42. 


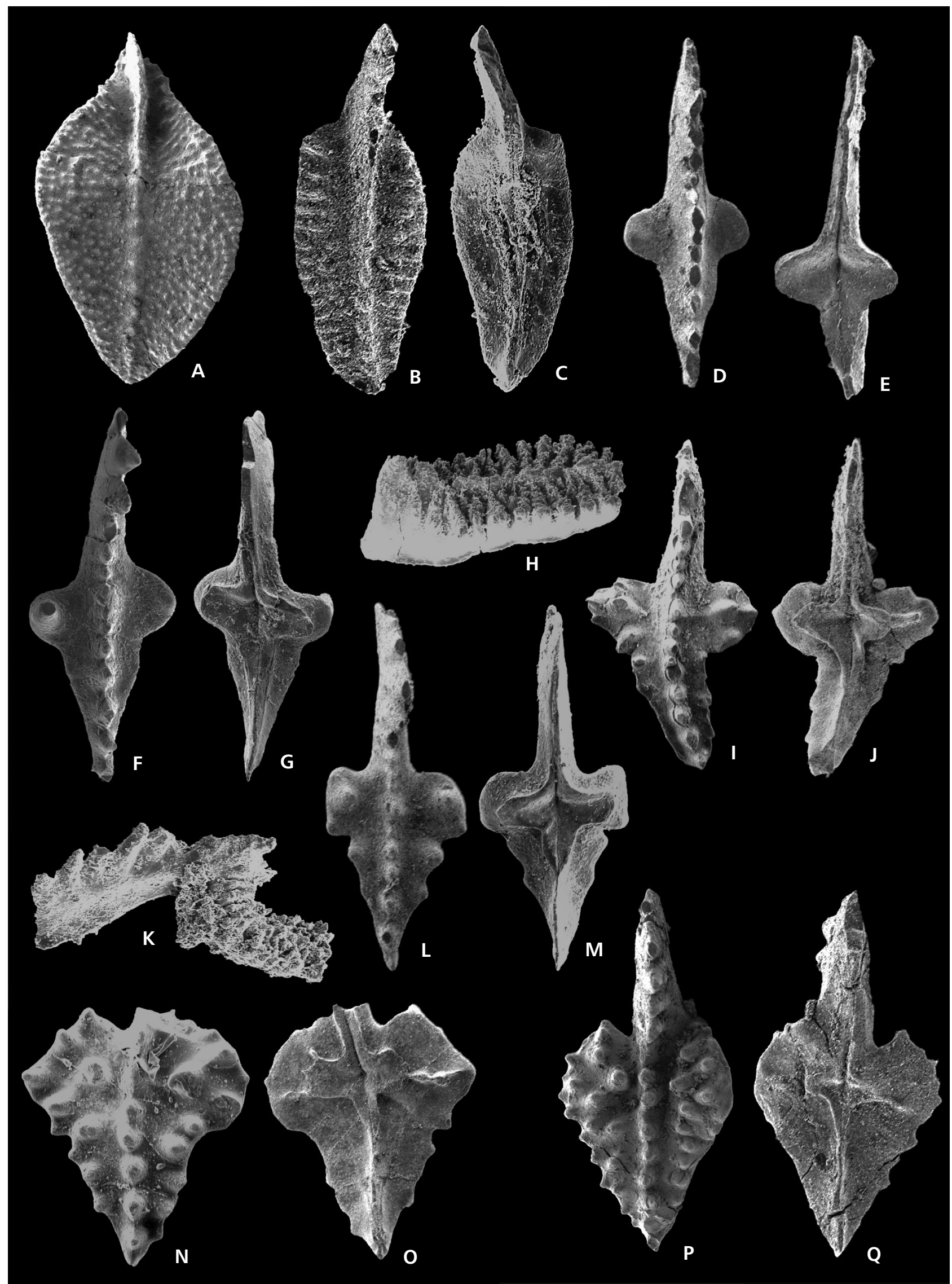


2003 Schmidtognathus hermanni Ziegler. - Aboussalam, pl. 20 , figs 11,12 ; pl. 21 , figs $13,16,17$, pl. 22 , figs $1-5$.

2008 Schmidtognathus hermanni Ziegler. - Liao \& Valenzuela-Ríos, pp. 9, 14, figs 5B, C.

Remarks. - The elongated asymmetric platform bears broad marginal ridges and is constricted in the anterior part. The outer anterior half of the platform is wider than the inner anterior half of the platform. The carina consists of completely fused nodes and is slightly curved. The anteriormost part of the platform and the free blade are missing. The large basal pit of Fig. $5 \mathrm{~K}$ is clearly asymmetric, somewhat L-shaped and has raised margins.

The specimen differs from Schm. pietzneri by the more posterior position of the greatest platform width in the former.

Stratigraphical distribution. - The species ranges from the base of the hermanni Zone up to within the norrisi Zone (Aboussalam \& Becker 2007).

Material. - 1 specimen from samples Vi-I/33 (1).

\section{Schmidtognathus pietzneri Ziegler, 1966}

Figure 5G

1966 Schmidtognathus pietzneri n. sp.; Ziegler, pp. 666, 667, pl. 2, figs 11-25.

1973 Schmidtognathus pietzneri Ziegler. - Ziegler (ed.), Catalogue of conodonts, Vol. I, p. 431, Schmidtognathus, pl. 1, fig. 2.

1980 Schmidtognathus pietzneri Ziegler. - Bultynck \& Hollard, pl. 9, figs 7, 8 .

2003 Schmidtognathus pietzneri Ziegler. - Aboussalam, p. 193, pl. 21, figs 5-21.

2008 Schmidtognathus pietzneri Ziegler. - Liao \& Valenzuela-Ríos, figs 5G, $\mathrm{H}$.

Remarks. - The long and narrow platform is slightly curved sidewards. The platform margins bear nodes and are separated from the carina by adcarinal grooves. The outer adcarinal trough is deep and rather wide. The anterior platform margins join the free blade at different positions. The free blade is formed by almost completely fused denticles and continues into the slightly curved carina, consisting of completely fused nodes and reaching the posterior tip of the platform. The asymmetric basal pit is situated in the anterior half of the platform.

The species is distinguished from Schm. wittekindti by the pointed posterior part of the platform and the extra row of nodes parallel to the carina on both sides in the latter.

Stratigraphical distribution. - The species occurs from the base of the hermanni Zone (Ziegler 1973) up into the Upper disparilis Zone (Bultynck \& Hollard 1980, Narkiewicz \& Bultynck 2010).

Material. - 1 specimen from sample Vi-I/33 (1).

\section{Schmidtognathus wittekindti Ziegler, 1966}

Figure 5J

1966 Schmidtognathus wittekindti n. sp.; Ziegler, pp. 665, 666, pl. 1, figs 11-16; pl. 2, figs 1-10.

1973 Schmidtognathus wittekindti Ziegler. - Ziegler, Catalogue of conodonts, vol. 1, pp. 433-434, Schmidtognathus, pl. 1, fig. 1.

2003 Schmidtognathus wittekindti Ziegler. - Aboussalam, pp. 193, 194, pl. 22, figs 6-10.

Remarks. - The specimen has a long, narrow and pointed platform ornamented with a row of very closely spaced nodes on both sides of the carina. In lateral view the specimen is markedly arched and shows a rather thick platform. The free blade is broken. The small asymmetric basal pit is situated in the anterior half of the platform.

The specimen differs from Schm. pietzneri and Schm. hermanni by the presence of the rows of nodes parallel to the carina, between the carina and the marginal platform nodes.

Stratigraphical distribution. - The species is found from the base of the hermanni Zone up to within the norrisi Zone (Ziegler 1973).

Material. - 2 specimens in samples Vi-I/34A (1) and $\mathrm{Vi}-\mathrm{I} / 35$ (1).

\section{Genus Skeletognathus Sandberg, Ziegler \& Bultynck, 1989}

Type species. - Polygnathus norrisi Uyeno, 1967.

\section{Skeletognathus norrisi (Uyeno, 1967)}

Figure $6 \mathrm{H}, \mathrm{K}$

1967 Polygnathus norrisi Uyeno; pp. 10, 11, pl. 2, figs 4, 5.

1980 Polygnathus norrisi Uyeno. - Bultynck \& Hollard, p. 44, pl. VIII, figs 12a, c.

1989 Skeletognathus norrisi (Uyeno). - Sandberg et al., p. 214 , pl. 5, figs $1-12$.

2001 Skeletognathus norrisi (Uyeno). - Liao et al., pp. 41, 42, pl. 4, figs 22-24.

2003 Skeletognathus norrisi (Uyeno). - Aboussalam, p. 194, pl. 9, fig. 6. 
2008 Skeletognathus norrisi (Uyeno). - Liao \& Valenzuela-Ríos, figs $6 \mathrm{C}-\mathrm{F}$.

Remarks. - The retrieved specimens show irregular plates on the upper side of the platform and subparallel platform margins. The posterior platform margin is rounded. The platform plates are merged together on the lower side of the platform. On the lower platform a forrowed keel is present. The free blade is missing. The Pb-element (Fig. 6H) has a high free blade with inclined posterior denticle. The platform is deformed and shows, similar to the Pa-element, irregular plates on its upper surface. The lower side of the platform is covered with sediment.

Stratigraphical distribution. - The species ranges from the base of the norrisi Zone up into the transitans Zone (MN 4) in the Lower Frasnian according to Sandberg et al. (1989). According to Klapper \& Johnson (1990) the species has its upper range within the MN2 Zone.

Material. - 6 specimens from samples Vi-I/35 (1Pa, $2 \mathrm{~Pb})$, Vi-I/35A (1 Pb), Vi-I/36A (2 Pb).

\section{Genus Tortodus Weddige, 1977}

Type species. - Polygnathus kockelianus Bischoff \& Ziegler, 1957.

\section{Tortodus bultyncki Aboussalam, 2003}

Figure 5E

2003 Tortodus bultyncki n. sp.; Aboussalam, p. 197, pl. 25, figs $1-3$.

Remarks. - The long, narrow and smooth platform is slightly bent downwards in the posterior part and is widest in the middle part. The blade shows a light torsion and changes sides of the platform from the anterior to the posterior end. The blade consists of large denticles that are partially fused posterior of the pit and only fused at the base in the rest of the blade. The denticles are somewhat narrower in the middle part of the blade. The large basal pit is situated under the widest part of the platform.

The species differs from $T$. weddigei by the slender platform shape, the lack of ornamentation on the upper platform and by the different denticulation pattern of the blade (3-4 isolated large denticles in the posterior part of the blade in $T$. weddigei).

Stratigraphical distribution. - The species is found in the upper ansatus Zone (Sparling 1995) and ranges up into the upper part of the disparilis Zone (Aboussalam 2003).
Material. - 1 specimen from sample Vi-I/33A.

Tortodus caelatus (Bryant, 1921) Figure 5B, C

1921 Polygnathus caelatus n. sp.; Bryant, p. 27, pl. 13, figs $5,6,8,9,11,12,13$ (non pl. 13, figs $1-4,7=$ T. aff. caelatus).

1980 Polygnathus beckmanni Bischoff \& Ziegler. - Bultynck \& Hollard, p. 42, pl. 8, fig. 9.

1987 Polygnathus beckmanni Bischoff \& Ziegler. - Bultynck, p. 181, pl. 9, fig. 18.

2003 Tortodus caelatus (Bryant, 1921). - Aboussalam, pp. 197, 198, pl. 26, figs 1-4.

Remarks. - The specimen has a long platform with a carina formed by two large and high nodes in its anteriormost part and continues into a row of partially fused decreasing nodes. Above the pit the carina nodes are again somewhat larger and less fused. The posteriormost part of the carina is formed by a row of small-aligned nodes and reaches the posterior tip of the platform. The carina is straight with the posterior part that is strongly curved. The widest part of the platform is located at midlength. The platform is ornamented with strong nodes, loosely aligned into wide rows parallel to the carina, in the middle part of the platform. The basal pit is large and located in the middle part of the platform.

The specimens differ from $T$. schultzei by the lack of strong torsion of the blade and the absence of four strong and separated denticles posterior of the basal pit.

Stratigraphical distribution. - The species is found from the base of the Middle varcus (ansatus) Zone till in the lower part of the Frasnian (Aboussalam 2003).

Material. - 1 specimen from sample Vi-I/30.

\section{Tortodus cf. T. kockelianus kockelianus (Bischoff \& Ziegler, 1957)}

Figure 4F, G

1957 Polygnathus kockeliana n. sp.; Bischoff \& Ziegler, p. 91, pl. 2, figs 1-12.

1977 Tortodus kockelianus kockelianus (Bischoff \& Ziegler). - Weddige, pp. 328, 329, pl. 3, fig. 52.

1985 Polygnathus kockelianus kockelianus Bischoff \& Ziegler. - Bultynck, pl. 7, fig. 19.

2009 Tortodus kockelianus kockelianus (Bischoff \& Ziegler). - Berkyová, pp. 682-684, figs 6A-C, E-G.

Remarks. - The figured specimen has a smooth platform that is widest around the pit and decreasing in width anteriorly 
and posteriorly. The platform is broken and cracked and missing the posterior part. The carina is formed by partially fused high denticles, decreasing in size posteriorward. The large pit is situated below the widest part of the platform. The keel is bent laterally (as far as the posterior platform is preserved), indicating the typical bent in the posterior platform of T. k. kockelianus.

The specimen differs from $T$. intermedius by the presence of a well-developed platform and from $T$. variabilis by the lack of ornamentation on the platform surface. It can be distinguished from $T$. $k$. australis by the denticles of the carina that remain hight till the posterior end and the more restricted platform development in the latter.

Stratigraphical distribution. - The first appearance of the species indicates the base of the kockelianus Zone, ranges up to the lowermost part of the ensensis Zone (Weddige 1977, Belka et al. 1997).

Material. - 2 specimens from samples Vi-I/15 (1), Vi-I/16 (1).

\section{Tortodus aff. T. schultzei Aboussalam, 2003}

Figure 5D

2003 Tortodus schultzei n. sp.; Aboussalam, pp. 199, 200, fig. 51, pl. 25, figs 10-12.

Remarks. - The blade of the figured specimen shows torsion and bears large equal sized denticles. Because of the broken state of the platform denticles their height evolution on the platform is not clear. The platform is narrow at the posterior end and is widest halfway, where the outer platform abruptly finished. The inner platform side is ornamented with marginal nodes mostly situated in the anterior part; the outer platform bears some small marginal nodes. The posterior platform half bears four strong denticles. An inner platform that continues till the anterior end, only slightly narrowing compared to midlength, is a characteristic that is not found in T. schultzei. In the latter the inner platform distinctly wedges out to the anterior end. Some specimens assigned to $T$. caelatus show this asymmetric platform, but differ from the figured specimen in having blade denticles that gradually decrease in size to the posterior part of the blade. Since so far only one specimen of T. schultzei has been found and described (holotype), the variability within the species is not known and the specimen figured here cannot be placed with certainty within the species.

Stratigraphical distribution. - The sample is situated in the semialternans Zone. T. schultzei is found in the upper part of the ansatus Zone and is reported from the Anti-Atlas (Aboussalam 2003).

Material. - 1 specimen in sample Vi-I/29.

\section{Conclusions}

The conodont biostratigraphic study of a selected part of the Villech section in the Spanish Central Pyrenees reveals deposits of Eifelian, Givetian and lowermost Frasnian age, providing the first elaborated conodont biostratigraphic framework for the Eifelian in the Compte "subfacies area". The Eifelian costatus, kockelianus and eiflius zones, the Givetian rhenanus-varcus, ansatus, semialternans, hermanni, disparilis and norrisi zones and the Frasnian MN1 Zone are identified. The australis Zone has not been recognized (T. kockelianus australis is not found in the section). The ensensis and hemiansatus zones have not been found either due to a covered interval in the section. Because of that the Eifelian- Givetian boundary can, so far, not be accurately positioned in the Villech section.

A thin black limestone/ black shale deposit, a hypoxic interval situated in the semialternans Zone in the Villech section, is possibly the local signature of the upper expression of the Taghanic event, one of the most important global extinction events in the Middle Paleozoic, which is recognized for the first time in the Spanish Central Pyrenees. The inconsistent thickness variation of the conodont zones in the Villech, Compte and Renanué sections and/or the possible absence of certain conodont zones suggest synsedimentary tectonic activity in the area in the Middle Devonian.

\section{Acknowledgements}

The authors thank G. Klapper and K. Narkiewicz for their kindly provided constructive reviews. This work is a contribution to IGCP-596 and has been supported by the Spanish Research Project CGL2011-24775. The DAAD (J-C L) and the Alexander von Humboldt-Stiftung (JIV-R) supported earlier activities of this research. A UNESCO-German Committee (J-C. L \& JIV-R) travel grant was used to attend at the IGCP 596 Opening Meeting in Graz, September 2011. We are grateful to the SCSIE (Servicio Central de Soporte a la Investigación Experimental) of the University of Valencia for technical support. C. Gentilini and M. Tonelli (Università di Modena e Reggio Emilia, Italy) are thanked for their help with the SEM imaging.

\section{References}

Aвoussalam, Z.S. 2003. Das "Taghanic-Event" im höheren Mittlel-Devon von West-Europa und Marokko. Münstersche Forschungen zur Geologie und Paläontologie 97, 1-330.

Aboussalam, Z.S. \& BeCKer, R.T. 2007. New upper Givetian to basal Frasnian conodont faunas from the Tafilalt (Anti-Atlas, Southern Morocco). Geological Quarterly 51(4), 345-374.

Belka, Z., Bultynck, P. \& Kaufmann, B. 1997. Conodont based quantitative biostratigraphy for the Eifelian of the eastern 
Anti-Atlas, Morocco. Geological Society of America Bulletin 109(6), 643-651.

DOI 10.1130/0016-7606(1997)109<0643:CBQBFT>2.3.CO;2

Berkyová, S. 2009. Lower-Middle Devonian (upper EmsianEifelian, serotinus-kockelianus zones) conodont faunas from the Prague Basin, the Czech Republic. Bulletin of Geosciences 84(4), 667-686. DOI 10.3140/bull.geosci.1153

Bischoff, G. \& Ziegler, W. 1957. Die Conodontenchronologie des Mittel-Devons und des tiefsten Ober-Devons. Abhandlungen der Hessnschen Landesamtes für Bodenforschung 2, $1-136$.

Boersma, K.T. 1973. Devonian and Lower Carboniferous conodont biostratigraphy, Spanish Central Pyrenees. Leidse Geologische Mededelingen 49, 303-377.

Bryant, W.L. 1921. The Genesee conodonts. Bulletin of the Buffalo Society of Natural Sciences 13(2), 1-59.

Branson, E.B. \& Mehl, M.G. 1933. Conodont studies 1, 2. University of Missouri Studies 8(1-2), 1-72, 77-167.

Branson, E.B. \& Mehl, M.G. 1938. The conodont genus Icriodus and its stratigraphic distribution. Journal of Paleontology 12, 156-166.

Bultynck, P. 1985. Lower Devonian (Emsian) - Middle Devonian (Eifelian and lowermost Givetian) conodont successions from the Ma'der and the Tafilalt, southern Morocco. Courier Forschunsgs-Institut Senckenberg 75, 261-286.

Bultynck, P. 1987. Pelagic and neritic conodont successions from the Givetian of pre-Sahara Morocco and the Ardennes. Bulletin de l'Institut Royal des Sciences Naturelles de Belgique, Sciences de la Terre 57, 149-181.

Bultynck, P. \& Hollard, H. 1980. Distribution comparée de Conodontes et Goniatites dévoniens des plained du Dra, du Ma'der et du Tafilalt (Maroc). Aardkundige Mededelingen 1, 9-73.

Bultynck, P. \& Jacobs, L. 1981. Conodontes et sédimentologie des couches de passage u Givetien au Frasnien dans le nord du Tafilalt et dans le Ma'der (Maroc présaharien). Bulletin de l'Institut Royal des Sciences Naturelles de Belgique, Sciences de la Terre 53(2), 1-24.

Gouwy, S. 2010. Middle Devonian conodonts of the NW margin of Gondwana. 197 pp. PhD thesis, University of Valencia, Spain and University of Modena and Reggio Emilia, Italy.

Gouwy, S., Benfrika, El M., Helsen, S. \& Bultynck, P. 1999. Late Emsian to early Givetian conodont succession in the Tiflet Area (North-Western Meseta, Central Morocco). Travaux de l'Institut de Sciences de Rabat Série Géographie Physique 20,1-10.

Gouwy, S. \& Bultynck, P. 2002. Graphic correlation of Middle Devonian sections in the Ardenne region (Belgium) and the Mader-Tafilalt region (Morocco): development of a Middle Devonian composite standard, 105-109. In Degryse, P. \& Sintubin, M. (eds) Contributions to the Geology of Belgium and Northwest Europe. Proceedings of the first Geologica Belgica International Meeting, Leuven, 11-15 September 2002 Aardkundige Mededelingen 12.

Gouwy, S. \& Bultynck, P. 2003. Conodont based graphic correlation of the Middle Devonian formations of the Ardennes (Belgium): implications for stratigraphy and construction of a regional composite. Revista Española de Micropaleontología 35(3), 315-344.

Gouwy, S., Haydukiewicz, J. \& Bultynck, P. 2007. Conodontbased graphic correlation of upper Givetian-Frasnian sections of the Eastern Anti-Atlas (Morocco). Geological Quarterly 51(4), 375-392.

Hartevelt, J.J.A. 1970. Geology of the Upper Segre and Valira valleys, Central Pyrenees, Andorra/Spain. Leidse Geologische Mededelingen 45, 167-236.

Hinde, G.J. 1879. On conodonts from the Chazy and Cincinnati group of the Cambro- Silurian, and from the Hamilton and Genesee shale divisions of the Devonian, in Canada and the United States. Geological Society of London, Quarterly Journal 35, 351-369.

Khalymbadzha, V.G. \& Chernysheva, N.G. 1970. Konodonty v. Ancyrodella is devonskikh otlozheniy volgo-kamskogo kraia i ikh stratigrahicheskoe znachenie, 81-103. In ULIANOVA-LENINA, V.I. (ed.) Biostratigrafia i paleontologia paleozoiskikh otloszheniy vostoka russkoj platformia i zapadnogo priuralia. Kazanskiy ordena trudivogo krasnogo znameni gosudarstvenniy universitet, Kazan.

KLAPPER, G. 1971. Sequence within the conodont genus Polygnathus in the New York lower Middle Devonian. Geologica et Paleontologica, 5, 59-79.

KLAPPER, G. 1985. Sequence in conodont genus Ancyrodella in Lower asymmetricus Zone (earliest Frasnian, Upper Devonian) of the Montagne Noire, France. Palaeontographica, Abteilung A 188 (1-3), 19-34.

Klapper, G. 1989. The Montagne Noire Frasnian (Upper Devonian) conodont succession, 449-468. In McMillan, N.J. et al. (eds) Devonian of the World. Canadian Society of Petroleum Geologists, Memoir 14(3).

KLAPPER, G. 2000. Species of Spathognathodontidae and Polygnathidae (Conodonta) in the recognition of Upper Devonian stage boundaries. Courier Forschungs-Institut Senckenberg 220, 153-159.

KLAPPER, G. \& JoHnson, J.G. 1980. Endemism and dispersal of Devonian conodonts. Journal of Paleontology 54(2), 400-455.

KlAPPER, G. \& Johnson, J.G. 1990. Revision of the Middle Devonian conodont zones. Journal of Paleontology 64(6), 902-941.

KLAPPER, G., PhILIP, G.M. \& JACKSON, J.H. 1970. Revision of the Polygnathus varcus group (Conodonta, Middle Devonian). Neues Jahrbuch für Geologie und Paläontologie, Monatshefte $11,650-667$.

Klapper, G. \& Ziegler, W. 1977. Distribution of conodonts in Lower/Middle Devonian boundary beds of the Barrandian. 4 pp. Unpublished report, field conference International Subcommission on Devonian Stratigraphy, Prague.

Klapper, G., Ziegler, W. \& Mashkova, T.V. 1978. Conodonts and classification of Lower-Middle Devonian boundary beds in the Barrandian area of Czechoslovakia. Geologica et Paleontologica 12, 103-115.

KRALICK, J.A. 1994. The conodont genus Ancyrodella in the Middle Genesee Formation (Lower Upper Devonian, Frasnian) western New York. Journal of Paleontology 68(6), 1384-1395.

Lane, H.R., Müller, K.J. \& Ziegler, W. 1979. Devonian and Carboniferous conodonts from Perak, Malaysia. Geologica et Paleontologica 13, 213-226.

Liao, J.-C., Königshof, P., Valenzuela-Ríos, J.I. \& Schindler, E. 2008. Depositional environment interpretation and development of the Renanué section (Upper Eifelian-Lower Frasnian; Pyrenees, N. Spain. Bulletin of Geosciences 83(4), 481-490. DOI 10.3140/bull.geosci.2008.04.481 
LiaO, J.-C. \& VAlenzuela-Ríos, J.I. 2008. Givetian and early Frasnian conodonts from the Compte section (Middle-Upper Devonian, Spanish Central Pyrenees). Geological Quarterly $52(1), 1-18$.

Liao, J.-C., Valenzuela-Ríos, J.I. \& Rodríguez, S. 2001. Descripción de los conodontos del Givetiense y Frasniense inferior (Devónico) de Renanué (Pirineos Aragoneses). Coloquios de Paleontología 52, 13-45.

MeY, P.H.W. 1967. Evolution of the Pyrenean Basins during the Late Paleozoic. International Symposium on the Devonian Systems 2, 1157-1166. Calgary.

MilleR, G.C. 2007. Growth in early species of the conodont Ancyrodella and implications for correlation of the Middle- Upper Devonian boundary. Geological Quarterly 51(4), 334-352.

Montesinos, J.R. \& SAnz-López, J. 1999. Ammonoideos del Devonico Inferior y Medio en el Pirineo Oriental y Central. Antecedentes históricos y nuevos hallazgos. Revista Española de Paleontología, No. Extraordinario Homenaje Prof. J. Truyols, 97-108.

Murphy, M.A., Valenzuela-Ríos, J.I. \& Carls, P. 2004. On classification of Pridoli (Silurian)-Lochkovian (Devonian) Spathognathodontidae (conodonts). University of California, Riverside, Campus Museum Contributions 6, 1-25.

Narkiewicz, K. \& Bultynck, P. 2007. Conodont biostratigraphy of shallow marine Givetian deposits from the Radom-Lublin area, SE Poland. Geological Quarterly 51(4), 419-443.

Narkiewicz, K. \& Bultynck, P. 2010. The Upper Givetian (Middle Devonian) subterminus conodont Zone in North America, Europe and North Africa. Journal of Paleontology 84(4), 588-625. DOI 10.1666/10-029.1

NorRis, A.W. \& UyENO, T.T. 1982. Devonian rocks of the Lake Winnipegosis-Lake Manitoba outcrop belt, Manitoba. Geological Survey of Canada, Memoirs 392, 1-248.

OliviERI, R. 1985. Middle and Late Devonian conodonts from Southwestern Sardinia. Bolletino della Società Paleontologica Italiana 23(2), 269-310.

ORR, W. \& KLAPPER, G. 1968. Two new conodont species from Middle-Upper Devonian boundary beds of Indiana and New York. Journal of Paleontology 42(4), 1066-1076.

Over, D.J. 2007. Conodont biostratigraphy of the Chattanooga shale, Middle and Upper Devonian, southern Appalachian Basin, Eastern United States. Journal of Paleontology 81(6), 1194-1217. DOI 10.1666/06-056R.1

Pollock, C.A. 1968. Lower Upper Devonian conodonts from Alberta, Canada. Journal of Paleontology 42(2), 414-443.

SAndberg, C.A, Ziegler, W. \& Bultynck, P. 1989. New standard conodont zones and early Ancyrodella phylogeny across Middle-Upper Devonian boundary. Courier ForschungsInstitut Senckenberg 110, 195-230.

SANZ-LÓPEZ, J. 1995. Estratigrafía y bioestratigrafía (conodontos) del Silùrico superior-Carbonifero inferior del Pirineo oriental y central. $717 \mathrm{pp}$. PhD thesis, Faculty of Geology, University of Barcelona.

SANZ-LÓPEZ, J. 2002. Devonian and Carboniferous pre-Stephanian rocks from the Pyrenees, 367-389. In GARCíA-LóPEZ, S. \& BASTIDA, F. (eds) Palaeozoic conodonts from Northern Spain. Instituto Geológico y Minero de España, serie Cuadernos del Museo Geominero 1.
SAvage, N. 1995. Middle Devonian conodonts from the Watleigh limestone, southeastern Alaska. Journal of Paleontology 69(3), 540-555.

SPARLING, D.R. 1983. Conodont biostratigraphy and biofacies of lower Middle Devonian limestones, north-central Ohio. Journal of Paleontology 57, 825-864.

Sparling, D.R. 1988. Middle Devonian stratigraphy and conodont biostratigraphy, North-Central Ohio. Ohio Journal of Science 88(1), 2-18.

Sparling, D.R. 1995. Conodonts from the Middle Devonian Plum Brook Shale of north-central Ohio. Journal of Paleontology 69, 1123-1139.

ULRICH, E.O. \& BASSLER, R.S. 1926. A classification of the toothlike fossils, conodonts, with discription of the American Devonian and Mississippian species. United States National Museum Proceedings 68(12), 1-63.

DOI 10.5479/si.00963801.68-2613.1

Uyeno, T.T. 1967. Conodont zonation, Waterways Formation (Upper Devonian), north-eastern central Alberta. Geological Survey of Canada, Paper 67(30), 1-20.

Valenzuela-Ríos, J.I. \& Liao, J.-C. 2006. Annotations to Devonian Correlation Table, R 357-360 di-ds 06: Spanish Central Pyrenees, southern part. Senckenbergiana lethaia 86(1), 105-107.

VOdRÁŽKOVÁ, S., KLAPPER, G. \& MuRPHY, M.A. 2011. Early Middle Devonian conodont faunas (Eifelian, costatus-kockelianus zones) from the Roberts Mountains and adjacent areas in central Nevada. Bulletin of Geosciences 86(4), 737-764. DOI 10.3140/bull.geosci.1292

Walliser, O. \& Bultynck, P. 2011. Extinctions, survival and innovations of conodont species during the Kačák Episode (Eifelian-Givetian) in south-eastern Morocco. Bulletin de l'Institut Royal des Sciences Naturelles de Belgique, Sciences de la Terre 81, 5-25.

Weddige, K. 1977. Die Conodonten der Eifel-Stufe im Typusgebiet und in benachbarten Faziesgebieten. Seckenbergiana lethaia 65, 179-223.

WIRTH, M. 1967. Zur Gliederung des höheren Paläozoikums (Givet-Namur) im Gebiet des Quinto Real (Westpyrenäen) mit Hilfe von Conodonten. Neues Jahrbuch für Geologie und Paläontologie 127(2), 179-244.

WitTeKindt, H. 1966. Zur Conodontenchronologie des Mitteldevons. Fortschritte in der Geologie von Rheinland und Westfalen 9, 621-646.

ZIEGLER, W. 1966. Eine Verfeinung der Conodontengliederung and der Grenze Mittel/OberDevon. Fortschritte in der Geologie von Rheinland und Westfalen 9, 647-676.

ZIEGLER, W. 1973. Catalogue of conodonts, Volume 1. 504 pp. E. Schweizerbart'sche Verlagsbuchhandlung, Stuttgart.

Ziegler, W. \& KLAPPeR, G. 1982. The disparilis conodont Zone, the proposed level for the Middle-Upper Devonian boundary. Courier Forschungs-Institut Senckenberg 55, 463-492.

Ziegler, W., Klapper, G. \& JohnSON, J.G. 1976. Redefinition and subdivision of the varcus-Zone (conodonts, Middle-?Upper Devonian in Europe and North America. Geologica et Palaeontologica 10, 109-140.

Zwart, H.J. 1979. The Geology of the Central Pyrenees. Leidse Geologische Mededelingen 50, 1-74. 